\title{
Antimicrobial and cytotoxic activity of (thio)alkyl hexopyranosides, nonionic glycolipid mimetics
}

\author{
Petr Džubák ${ }^{\mathrm{a}}$, Soňa Gurská ${ }^{\mathrm{a}}$, Kateřina Bogdanováa ${ }^{\mathrm{a}}$, Daniela Uhríkovác ${ }^{\mathrm{c}}$, Nina Kanjaková ${ }^{\mathrm{c}}$, Sophie Combet $^{\mathrm{d}}$, \\ Tomáš Klunda ${ }^{\mathrm{b}}$ ，Milan Kolář ${ }^{\mathrm{a}}$ ，Marian Hajdúch ${ }^{\mathrm{a}, * *}$ ，Monika Polákováb,* \\ a Institute of Molecular and Translational Medicine, Faculty of Medicine and Dentistry, Palacky University Olomouc, Hnevotinska 5, 779 00, Olomouc, Czech Republic \\ b Institute of Chemistry, Center for Glycomics, Slovak Academy of Sciences, Dubravska cesta 9, SK-845 38, Bratislava, Slovakia \\ ${ }^{\mathrm{c}}$ Department of Physical Chemistry of Drugs, Faculty of Pharmacy, Comenius University in Bratislava, Odbojarov 10, 832 32, Bratislava, Slovakia \\ d Laboratoire Léon Brillouin (CEA/CNRS), CEA Saclay, 91191, Gif-sur-Yvette Cedex, France
}

\section{A R T I C LE IN F O}

\section{Keywords}

Alkyl glycoside

Glycolipid mimetic

Cytotoxicity

Antimicrobial activity

Cell cycle

SAXS

\begin{abstract}
A B S T R A C T
A series of 19 synthetic alkyl and thioalkyl glycosides derived from D-mannose, D-glucose and D-galactose and having $\mathrm{C}_{10}-\mathrm{C}_{16}$ aglycone were investigated for cytotoxic activity against 7 human cancer and 2 non-tumor cell lines as well as for antimicrobial potential on 12 bacterial and yeast strains. The most potent compounds were found to be tetradecyl and hexadecyl $\beta$-D-galactopyranosides $(\mathbf{1 8}, \mathbf{1 9})$, which showed the best cytotoxicity and therapeutic index against CCRF-CEM cancer cell line. Similar cytotoxic activity showed hexadecyl $\alpha$-D-mannopyranoside (5) but it also inhibited non-tumor cell lines. Because these two galactosides (18, 19) were inactive against all tested bacteria and yeast strains, they could be a target-specific for eukaryotic cells. On the other hand, $\beta$-D-glucopyranosides with tetradecyl (11) and hexadecyl (12) aglycone inhibited only Gram-positive bacterial strain Enterococcus faecalis. The studied glycosides induce changes in the lipid bilayer thickness and lateral phase separation at high concentration, as derived from SAXS experiments on POPC model membranes. In general, glucosides and galactosides exhibit more specific properties. Those with longer aglycone show high cytotoxicity and therefore, they are more promising candidates for cancer cell line targeted inhibition.
\end{abstract}

\section{Introduction}

Glycolipids are cell membrane amphiphilic components present in all living organisms. The hydrophilic carbohydrate portion is composed of one or more monosaccharide units linked by a glycosidic bond while the hydrophobic lipid moiety anchors them to the membrane. It is known that these compounds fulfill a large variety of functions that are important for many biological processes, such as recognition, cell adhesion and signaling that are influenced by membrane properties [1].

The glycolipid ability to be incorporated into the lipid bilayer may lead to either disruption or modification of the membrane structure. Many of glycolipids are also able to dissolve the lipid membrane yielding a disruption of the cells. Therefore, the surface tension of the membranes reduces, allowing water to flow into the cell and finally results in cell lysis. To enhance the efficiency of this action, a tuned balance between the hydrophilic and hydrophobic parts of the glycolipid is essential [2].
Among others, the sugar core, its stereochemistry and the structure of hydrophobic aglycone are the factors that determine the physical and chemical properties of the glycolipids [3].

The ability of the glycolipids to destabilize biological membrane determines their biomedicinal application as antifungal and antibacterial agents. Due to their antiviral and cytotoxic properties, they are a subject of interest as therapeutics and pharmaceutics.

Their low toxicity is an additional benefit, important for applications in agro, food and cosmetic industries [4].

The large potential of these compounds was an impulse for synthesis and evaluation of a series of synthetic glycolipid mimetics [5]. Alkyl glycosides is one group of such mimetics. The synthesis of such sugar-based amphiphiles is rapid [6] and, often, it requires just a few reaction steps. Moreover, these non-ionic surfactants are environmentally friendly, biocompatible and biodegradable.

The discovery of anticancer activity of fractions containing mixtures of diverse glycolipids isolated from edible plants [7] motivated the

\footnotetext{
* Corresponding author.

** Corresponding author.

E-mail addresses: marian.hajduch@upol.cz (M. Hajdúch); Monika.Polakova@savba.sk (M. Poláková)
} 
preparation of a series of synthetic decyl to hexadecyl $\alpha$ - and $\beta$-D-galactopyranosides. Some of them were moderately cytotoxic against 4 cancer cell lines with $\mathrm{IC}_{50}$ values at $\mu \mathrm{M}$ level. However, in some cases, equimolar mixtures of both anomers were even more cytotoxic towards several cancer cell lines than single anomers [8]. This was the case of the mixture of tetradecyl $\alpha / \beta$-D-galactopyranosides, which accentuates apoptosis of multiple myeloma cells by inducing DNA damage [9]. These are the only report on cytotoxicity of sugar-based amphiphiles.

Reports on antimicrobial activity of alkyl glycosides are rare. Nevertheless, the synthesis of a series of alkyl 2-, 3-, 4-deoxy, 2,3- and 3,4 -dideoxy glycosides was reported $[10,11]$. Among them, octyl and dodecyl 2-deoxy- $\beta$-D-arabino-hexopyranosides inhibit the growth of Enterococcus faecalis. This Gram-positive species is also highly sensitive to dodecyl 2,6-dideoxy $\alpha$-L-arabino-hexopyranoside, which is particularly active against another Gram-positive bacterium, Bacillus sp. [10]. Additionally, $\mathrm{Hu}$ et al. have shown that triazole glycolipids can reverse the bacterial MRSA phenotype and restore sensitivity to beta-lactam antibiotics [12]. Such activity may be important for the eradication of resistant bacteria in cystic fibrosis or, more generally, in the therapy of nosocomial infections.

In our previous study, we showed that antimicrobial activity of 14 synthetic alkyl and thioalkyl $\alpha$-D-mannopyranosides, with aglycone from hexyl to eicosyl, against 3 species (Gram-positive Staphylococcus aureus, Gram-negative Escherichia coli and yeast Candida albicans), depends on the aglycone length and on the type of glycosidic linkage ( $O$ - vs. $S$ - mannosides). Mannosides having (thio)dodecyl aglycones are the most potent antimicrobials, with $\mathrm{IC}_{50}$ at the micromolar level [13].

The eco-friendly nature of alkyl glycosides offers a broad potential for their study. We evaluated a broad variety of synthetic alkyl D-glycosides (glucosides, galactosides and mannosides), which include aglycone of selected length from decyl to hexadecyl. Moreover, because (thio)dodecyl mannosides are very active [13], both anomers of the corresponding glucoside and galactoside analogs were screened in this study.

This paper reports the investigation of the inhibitory potential of these synthetic sugar based amphiphiles against several Gram-positive (including methicillin-resistant Staphylococcus aureus), Gram-negative bacteria and yeasts, and 7 human cancer and 2 non-tumor lines. Due to the amphiphilic character of these molecules, the lipid bilayer of the cell membrane is a target of their biological activity. We examined structural changes of the model membrane palmitoyl-oleoyl-phosphatidylcholine (POPC) induced by selected glycosides, by Small angle X-ray scattering (SAXS).

\section{Results and discussion}

\subsection{Synthesis}

Tetradecyl $\alpha$-D-mannopyranoside (4) was prepared by a procedure previously utilized in the synthesis of various alkyl mannosides, including 1 [13], 2 [6], 3 [13] and 5 [6]. This 2 steps sequence led to the exclusive formation of 4 in $45 \%$ overall yield.

The synthesis of another neutral (thio)alkyl $\alpha$ - and $\beta$-D-glycopyranosides bearing hydrocarbon chains of different length $\left(\mathrm{C}_{10}-\mathrm{C}_{16}\right)$ was performed by a glycosylation reaction between the corresponding alcohol or thiol as an acceptor with peracetylated sugar donor upon activation with $\mathrm{BF}_{3} \cdot \mathrm{OEt}_{2}$ at room temperature (Scheme 1, Experimental section).
When the reaction was proceeded for $5 \mathrm{~h}$ in DCM, desired decyl glycosides $6 \mathbf{a}$ and 13a were obtained in moderate yields $(\sim 30 \%)$. Similar yields of all glycosides having longer, tetradecyl and hexadecyl aglycones, were achieved after $22 \mathrm{~h}$ in 1,2-dichloroethane.

$\alpha$ - and $\beta$-anomers of (thio)dodecyl glucoside and galactoside were separated from the corresponding anomeric mixtures. While dodecyl $\alpha / \beta$ glycosides were formed in approximately equimolar ratio after $24 \mathrm{~h}$, in the case of thio analogs, $\beta$-anomers were observed as major products within $5 \mathrm{~h}$. The purified isomers were identified based on a typical chemical shift for H-1. For dodecyl glycosides (7a, 8a and 14a, 15a), the $\mathrm{H}-1$ signal of $\alpha$-anomers was shifted more downfield by $0.6-1.1 \mathrm{ppm}$ than that of $\beta$-anomers. The same trend in chemical shifts of the anomeric H-1 was observed for the corresponding thio analogs 9a, 10a and 16a, 17a. In addition, for $\beta$-anomers of all (thio)dodecyl glycosides, C-1 atom resonated at higher ppm than that of the corresponding $\alpha$-anomer.

Finally, deacetylation of 6a-19a under Zemplen conditions (sodium methoxide in methanol) gave deprotected glycosides 6-19 with good yields.

\subsection{Biological assay}

\subsubsection{Cytotoxicity}

Compounds 1-19 (Fig. 1) were tested in vitro for their cytotoxic activity on seven cancer cell lines: A549 (human lung adenocarcinoma), CCRF-CEM (T-lymphoblastic leukemia), CEM-DNR (T-lymphoblastic leukemia, daunorubicin resistant), K562 (acute myeloid leukemia), K562-TAX (acute myeloid leukemia, overexpressing the P-glycoprotein), HCT116 (human colorectal cancer with wild-type p53), HCT116p53-/(human colorectal cancer with deleted p53), and on the two non-malignant cell lines BJ (human fibroblast) and MRC-5 (human lung fibroblasts). Cytotoxic activities are presented in Table 1 and are expressed as $\mathrm{IC}_{50}$ values.

The tested compounds showed $\mathrm{IC}_{50}$ values between $9.4 \mu \mathrm{M}$ and more than $100 \mu \mathrm{M}$.

The acute lymphoblastic leukemia CCRF-CEM cell line was the most sensitive to tested glycosides, particularly to $5,11,18$ and 19 IC $_{50}$ in the range of 9.4-20.3 $\mu \mathrm{M}$ ) bearing tetradecyl or hexadecyl aglycone, what implies correlation between aglycone length and cytotoxic activity. All the compounds were less active against its daunorubicin resistant CEM-DNR counterpart.

However, in the case of $\mathrm{K} 562$ and the corresponding drug-resistant K562-TAX lines, the cytotoxic activities of glucosides and galactosides are similar. A more significant difference was observed for decyl $\alpha$-D-mannoside (1) having 2.6 times higher cytotoxicity against K562 than $\mathrm{K} 562-\mathrm{TAX}$ ( $\mathrm{IC}_{50} 27.7 \mu \mathrm{M}$ vs. $69.4 \mu \mathrm{M}$ ). On the other hand, hexadecyl $\alpha$-D-mannoside (5) was 2.9 times more potent against resistant K562-TAX than K562 cell line ( $\mathrm{IC}_{50} 19.7 \mu \mathrm{M}$ vs. $57.3 \mu \mathrm{M}$ ). These results indicate that for the resistance are responsible other mechanisms than P-glycoprotein, which is common for both cell lines.

Except for decyl $\beta$-D-glucopyranoside (6) and decyl $\beta$-D-galactopyranoside (13), all other compounds are active against human lung adenocarcinoma A549. Only a slight increase in cytotoxic activity is observed with an elongation of alkyl lipid chain. Moreover, the impact of anomeric configuration is not significant. $\alpha$-Linked dodecyl $O$ - and $S$-glucosides 7 and 9 , as well as galactosides 14 and 16, were slightly

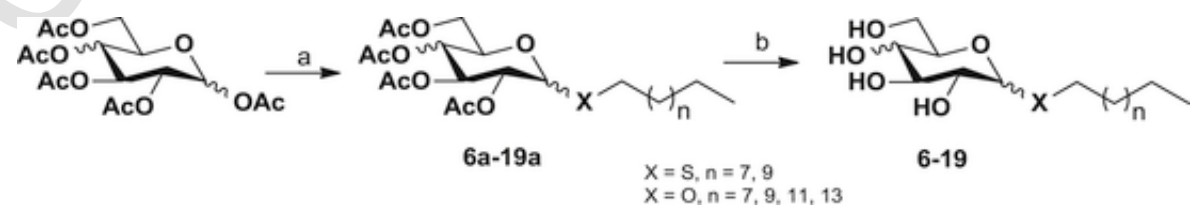

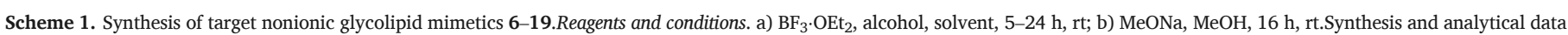
for compounds 1a [13], 2a [6], 3a [13] and 5a [6] were reported. 

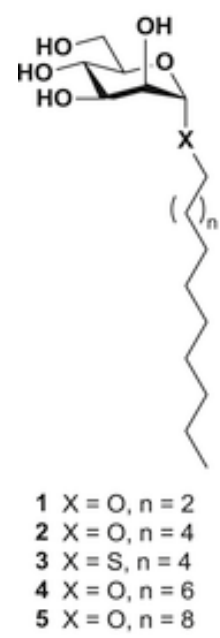

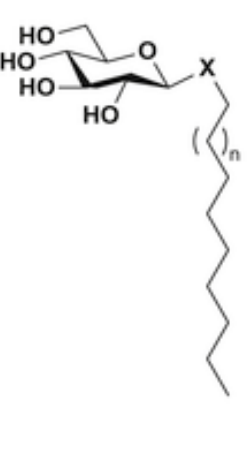

$$
\begin{array}{r}
6 X=0, n=2 \\
8 X=0, n=4 \\
10 X=S, n=4 \\
11 X=0, n=6 \\
12 X=0, n=8
\end{array}
$$
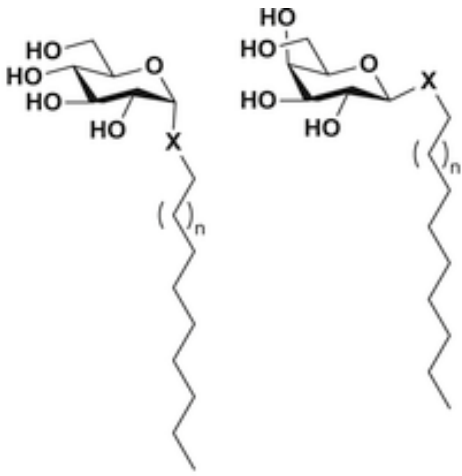

$$
7 \mathrm{X}=\mathrm{O}, \mathrm{n}=4
$$$$
9 \mathrm{X}=\mathrm{S}, \mathrm{n}=4
$$

$$
\begin{aligned}
& 13 X=O, n=2 \\
& 15 X=O, n=4 \\
& 17 X=S, n=4 \\
& 18 X=0, n=6 \\
& 19 X=0, n=8
\end{aligned}
$$

\begin{tabular}{|c|c|c|c|c|c|c|c|c|c|}
\hline \multirow[t]{2}{*}{ Comp } & \multicolumn{9}{|c|}{$\mathrm{IC}_{50}(\mu \mathrm{M})$} \\
\hline & A549 & CCRF-CEM & CEM-DNR & HCT116 & HCT116p53-- & K562 & K562-TAX & BJ & MRC-5 \\
\hline 1 & 74.1 & 75.7 & 91.7 & 73.7 & 86.5 & 27.2 & 69.4 & 85.8 & $>100$ \\
\hline 2 & 57.1 & 44.5 & 55.5 & 37.0 & 58.4 & 18.8 & 31.9 & 49.2 & 60.5 \\
\hline 3 & 62.3 & 56.6 & 61.4 & 52.6 & 60.3 & 56.5 & 57.5 & 88.1 & 96.5 \\
\hline 4 & 45.9 & 29.2 & 47.3 & 45.1 & 53.1 & 44.5 & 37.0 & 55.3 & 45.0 \\
\hline 5 & 47.9 & 15.6 & 26.2 & 47.6 & 52.8 & 57.3 & 19.7 & 35.1 & 22.7 \\
\hline 6 & $>100$ & 66.0 & 87.6 & $>100$ & $>100$ & 94.9 & $>100$ & $>100$ & $>100$ \\
\hline 7 & 58.7 & 37.2 & 45.4 & 66.5 & 72.3 & 36.2 & 43.2 & 86.1 & 71.3 \\
\hline 8 & 74.2 & 54.8 & $>100$ & 56.7 & 77.5 & 61.8 & 68.1 & 84.1 & $>100$ \\
\hline 9 & 53.9 & 54.4 & 80.2 & 52.1 & 64.7 & 62.2 & 64.2 & 61.7 & 66.3 \\
\hline 10 & 70.0 & 47.7 & 96.3 & 56.1 & 65.5 & 62.1 & 68.8 & 91.8 & $>100$ \\
\hline 11 & 58.8 & 20.3 & 47.9 & 55.9 & 60.7 & 47.8 & 51.9 & $>100$ & $>100$ \\
\hline 12 & 55.5 & 51.6 & 74.9 & 57.8 & 61.1 & 73.0 & 56.2 & 76.0 & 83.3 \\
\hline 13 & $>100$ & 81.9 & 94.7 & $>100$ & $>100$ & 98.2 & $>100$ & $>100$ & $>100$ \\
\hline 14 & 61.2 & 54.5 & 98.2 & 52.3 & 77.4 & 58.0 & 69.4 & 68.8 & $>100$ \\
\hline 15 & 79.8 & 53.4 & $>100$ & 64.3 & 89.4 & 62.8 & 72.2 & 95.4 & $>100$ \\
\hline 16 & 63.1 & 53.2 & 60.7 & 48.3 & 58.6 & 53.2 & 60.7 & 89.2 & 96.4 \\
\hline 17 & 77.3 & 55.6 & $>100$ & 65.6 & 79.6 & 55.2 & 69.6 & $>100$ & $>100$ \\
\hline 18 & 54.2 & 9.4 & 50.4 & 68.8 & 55.4 & 48.5 & 52.3 & $>100$ & 62.0 \\
\hline 19 & 50.1 & 16.4 & 46.2 & 67.9 & 64.6 & 62.2 & 43.6 & 62.7 & 74.9 \\
\hline
\end{tabular}

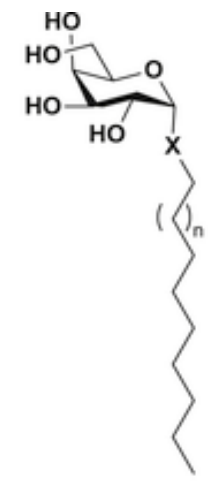

$$
14 X=O, n=4
$$

$16 \mathrm{X}=\mathrm{S}, \mathrm{n}=4$

Fig. 1. Structure of the nonionic glycosides used in this study.

Table 1

Cytotoxic activity of derivatives 1-19 on human malignant cell lines different tissue origin and drug resistance profile.

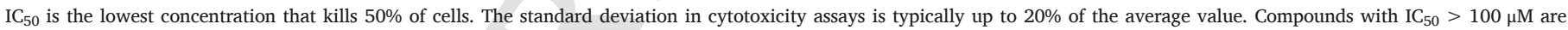
considered inactive.

more active than their $\beta$-analogs 8, 10, 15 and 17 . The most potent glycolipid is tetradecyl $\alpha$-D-mannoside (4) (IC $5045.9 \mu \mathrm{M}$ ).

Cytotoxicity of all glycosides tested against HCT116 and HCT116p53-- were similar. The most efficient were mannosides 2, 4 and 5, with $\mathrm{IC}_{50}$ below $50 \mu \mathrm{M}$ in the case of HCT116. Conversely, any effect of the aglycone length on the cytotoxicity of the glycosides against non-tumor lines BJ and MRC-5 was not observed. The most toxic are mannosides, in particular hexadecyl $\alpha$-D-mannoside (5) $\left(\mathrm{IC}_{50}<35.1 \mu \mathrm{M}\right)$. Some of the glucosides and galactosides inhibit these lines only weakly. Therefore, these glycosides are more suitable as anticancer drugs with favorable therapeutic index (TI).

$\mathrm{TI}$ value is the ratio between the average $\mathrm{IC}_{50}$ value of noncancer cell lines (MRC- 5 and $\mathrm{BJ}$ ) and the $\mathrm{IC}_{50}$ value of a given cancer cell line.

In general, glycolipids have the best selectivity (TI in a range from 9.1 to 2.27) for hematological CCRF-CEM (T-lymphoblastic leukemia), K562 (acute myeloid leukemia) and CEM-DNR (T-lymphoblastic leukemia, daunorubicin resistant) cell lines. The highest TI value among all tested compounds is observed for tetradecyl $\beta$-D-galactoside (18) (TI CCRF-CEM 9.10). Tetradecyl $\beta$-D-glucoside (11) also showed high TI (TI CCRF-CEM 5.36) against the same line and a similar TI (TI CCRF-CEM 4.20) was calculated for another galactoside 19 having two more carbon atoms in the aglycone chain. The $\beta$-glucoside $\mathbf{1 1}$ is the only compound with TI $>2$ against some of the multidrug-resistant cell lines (TI ${ }_{\text {CEM-DNR }}$ 2.27). It exhibits the same TI value for the K562 cell line ( $\left.\mathrm{TI}_{\mathrm{K} 562} 2.27\right)$. Higher TI values for the K562 cell line were calculated for $\alpha$-D-mannosides 1 and 2 (TI K562 3.76 and 2.88, respectively) having shorter aglycones. Some selectivity on the K532 line ( $\left.\mathrm{TI}_{\mathrm{K} 562} 2.17\right)$ also showed dodecyl $\alpha$-D-glucoside (7).

In a recent report [8], the cytotoxic activity of decyl to hexadecyl galactosides was assayed against 4 cancer cell lines, from which A549 and HCT116 cell lines were also used in this study. Cytotoxic activity of dodecyl galactosides 14 and 15 against the A549 cell line determined 
in the present study is very similar to those reported, while $\mathrm{IC}_{50}$ values for galactoside 19 were rather different. In case of HTC116 cell line, the $\mathrm{IC}_{50}$ values for these 3 galactosides differed, but there was a similar trend, elongation of the aglycone chain resulted in a decrease in cytotoxicity.

\subsubsection{Cell cycle analysis}

The effect of the most active tetradecyl $\beta$-D-galactoside (18) on the cell cycle was analyzed on CCRF-CEM cell line at $1 \times / 5 \times$ IC $_{50}$ concentrations $(9.39 / 46.95 \mu \mathrm{M})$ with 24 -h treatment (Table 2). Accumulation of cells in the G0/G1 and reduction in the $S$ phase of the cell cycle was observed, which was supported by the decrease of the DNA and RNA synthetic activity and increase of apoptotic cells percentage following the $5 \times \mathrm{IC}_{50}$ treatment.

\subsubsection{Antimicrobial activity}

Antimicrobial activity of the glycolipid mimetic 1-19 were tested against Gram-positive (Enterococcus faecalis CCM 4224, Staphylococcus aureus CCM 3953, methicillin-resistant $S$. aureus (MRSA) 4591 and fluoroquinolone-resistant $S$. haemolyticus $\mathrm{A} / 16568$ ) and Gram-negative (Escherichia coli CCM 3954, E. coli C/16702, Pseudomonas aeruginosa CCM 3955, P. aeruginosa A/16575) bacterial strains and yeasts (Candida albicans, C. krusei, C. tropicalis and C. parapsilosis).

Inhibitory activity of the glycolipids (Table 3 ) was determined and is expressed as minimal bactericidal concentration (MBC) and minimal inhibitory concentration (MIC).

All tested glycolipids were inactive against Gram-negative bacterial strains. These species (Escherichia coli and Pseudomonas aeruginosa) represent two of the most frequently Gram-negative pathogens isolated in humans. Moreover, none of the decyl glycosides inhibited any of the other 10 microorganisms tested.

All tested Candida strains were sensitive only to (thio)dodecyl $\beta$-glucosides, $\alpha$-galactosides and $\alpha$-mannosides.

The best inhibitors of $C$. albicans are $\alpha$-thioglycosides, mannoside 3 and galactoside 16 (both having MBC $50 \mu \mathrm{M}$ ), which were more bactericidal than their $O$-counterparts 2 and 14. $\beta$-Glucosides 8 and 10 exhibited weaker activity.

The same inhibition pattern is observed for C. krusei. Dodecyl glycosides 8 and 14 are less potent than their thio-counterparts 10 and 16. The latter compound is the most efficient $C$. krusei inhibitor, along with mannosides 2 and 3, all showing the same MBC $50 \mu \mathrm{M}$.

C. parapsilosis showed an inhibitory pattern identical to that of $C$. krusei, but the potency of the glycosides is slightly weaker. C. parapsilosis is the most sensitive to thiomannoside 3 , which showed bactericidal activity equal to that against the two Candida sp. strains (C. albicans, $C$. krusei) mentioned above.

C. tropicalis is sensitive to the same glycosides as C.albicans, but it is the weakest inhibited strain among the tested Candida sp. strains. The most potent glycosides (2, 3 and 16$)$ out of 6 active ones have the same bactericidal activity (MBC $100 \mu \mathrm{M})$.

In general, $S$-glycosides were more efficient Candida sp. strains inhibitors than their $O$-counterparts.
The Gram-positive strain E. faecalis is the most susceptible strain, since it was inhibited by ten glycosides. Comparing two active $\alpha$-galactosides, $S$-glycoside 16 (MBC $25 \mu \mathrm{M}$ ) is more efficient than its $O$-analogue 14, thus resembling the inhibitory pattern of all Candida sp. strains. Five out of seven tested glucosides possess bactericidal activity which increases with the elongation of the aglycone hydrocarbon chain. Hexadecyl $\beta$-D-glucoside 12 (MBC $25 \mu \mathrm{M})$ is the most bactericidal. It was inactive against all other microbes. Similarly, tetradecyl $\beta$-D-glucoside 11, as well as hexadecyl $\alpha$-D-mannoside 5 (both MBC $50 \mu \mathrm{M}$ ), are selective inhibitors of $E$. faecalis. However, (thio)dodecyl mannosides $\mathbf{2}$ and $\mathbf{3}$ are more bactericidal glycosides (MBC $25 \mu \mathrm{M}$ ), reaching the efficiency of 16.

Another Gram-positive strain, represented by the more virulent $S$. aureus, is sensitive to the same (thio)dodecyl glycosides as Candida sp. strains, and $S$-glycosides showed again better inhibitory potential. Among 19 tested glycosides, tetradecyl $\alpha$-D-mannoside (4) selectively inhibits this strain. Together with another mannoside 3 , they were the most bactericidal (MBC $25 \mu \mathrm{M}$ ). On the other hand, reduced potential of glucosides was observed. $S$. aureus was affected only by two of them.

4 (Thio)dodecyl glycosides (2, 3, 10 and 14) exhibit a bactericidal activity against MRSA at a level similar to that observed against $S$. aureus.

S. haemolyticus 16568 was the least sensitive to the tested glycolipids. Only two of them show some activity, but both bactericidal activity of dodecyl $\alpha$-D-mannoside (2) (MBC $200 \mu \mathrm{M}$ ) and bacteriostatic activity of dodecyl $\alpha$-D-galactoside (14) (MBC $200 \mu \mathrm{M}$ ) are quite weak.

The study reveals that alkyl glycosides as nonionic glycolipid mimetics can induce a bactericidal action. In general, glycosides were the most efficient inhibitors of $E$. faecalis, which is sensitive to ten of them. On the other hand, the mannosides as the broadest spectrum antimicrobials are able to inhibit 8 out of 12 tested microbial strains. Next, the length of the aglycone affects inhibitory activity. Decyl glycosides were completely inactive, while those with (thio)dodecyl aglycone were efficient on the majority of the tested strains. In addition, further elongation of glycolipid aglycone chain leads to selective inhibition of some strains (namely E. faecalis (compounds 5, 11 a 12) and $S$. aureus (comp. 4)). These conclusions are in agreement with our previous paper reporting on a brief study of antimicrobial properties of a series of $\alpha$-D-mannosides. Nonionic alkyl glycosides presented here affect $S$. aureus, E. faecalis and Candida sp. strains, but also show inactivity against $E$. coli and $P$. aeruginosa. The bactericidal activity of the most active glycolipids mimetics (MBC $25 \mu \mathrm{M}$ ) demonstrate their promising antimicrobial potential against some Gram-positive bacterial strains and yeast.

\subsection{Structural study of the model membrane}

As reported above, some of the studied glycosides are biologically active. These nonionic amphiphiles interact readily with the phospholipid bilayer of the biological membrane.

Table 2

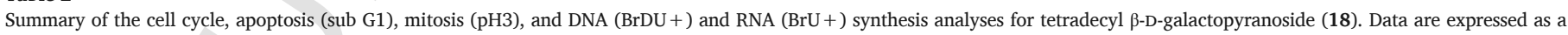
percentage of the total cellular population.

\begin{tabular}{|c|c|c|c|c|c|c|c|c|}
\hline \multirow[t]{2}{*}{ Comp. } & \multirow[t]{2}{*}{ Concentration $(\mu \mathrm{M})$} & \multicolumn{7}{|c|}{$\%$ of total cell populations } \\
\hline & & Sub-G1 (apoptosis) & G0/G1 & S & $\mathrm{G} 2 / \mathrm{M}$ & $\mathrm{pH} 3^{\operatorname{Ser} 10}+$ (mitosis) & BrDU + (DNA synthesis) & BrU + (RNA synthesis) \\
\hline Control & 0 & 2.18 & 38.40 & 42.36 & 19.25 & 2.10 & 37.48 & 42.05 \\
\hline 18 & 9.39 & 2.24 & 39.19 & 39.61 & 21.20 & 2.07 & 42.98 & 45.87 \\
\hline 18 & 46.95 & 12.73 & 48.24 & 31.25 & 20.51 & 1.62 & 26.90 & 15.16 \\
\hline
\end{tabular}


Table 3

Antimicrobial activity of derivatives 1-19 on bacterial strains.

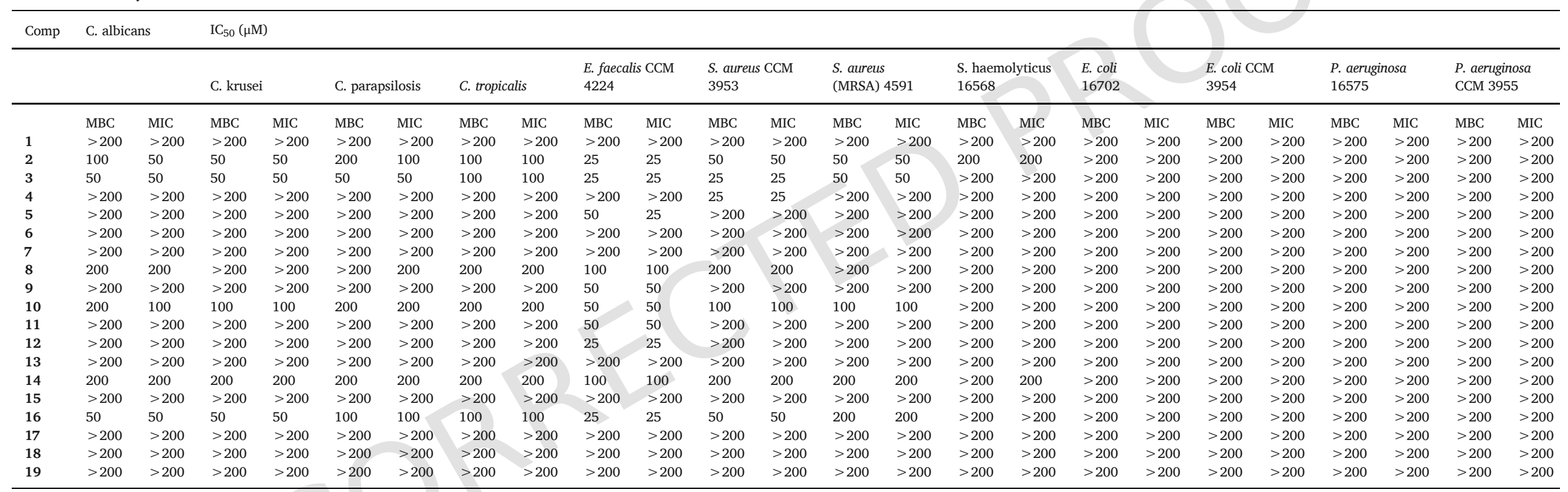

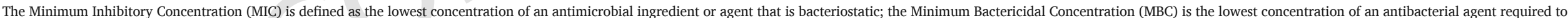

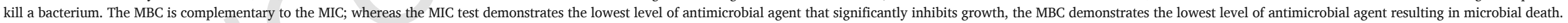


We studied the effect of selected glycosides (4, 11, 12, 18 and 19) on the lipid bilayer formed by zwitterionic phosphatidylcholine (POPC), intending to better understand the mechanism of their biological activity.

Hydrated POPC forms a liquid-crystalline lamellar phase $\left(\mathrm{L}_{\alpha}\right)$ in our studied temperature range $\left(25-60^{\circ} \mathrm{C}\right)[14]$. Small angle X-ray scattering (SAXS) experiments were performed to follow structural changes of bilayers induced by glycoside (GL) at $2 \mathrm{M}$ ratios (GL:POPC $=0.2$ and $0.5 \mathrm{~mol} / \mathrm{mol}$ ). Fig. 2 depicts typical SAXS patterns. Fully hydrated POPC shows two peaks (L1 and L2) characterizing a lamellar phase (Fig. 2 , A bottom) with repeat distance $d=65.30 \pm 0.01 \AA$ (at $25^{\circ} \mathrm{C}$ ), a value that agrees with the value $d=64.3 \AA$ reported for the same POPC in $200 \mathrm{mmol} / \mathrm{l}$ of $\mathrm{NaCl}$ [15]. All studied mixtures show lamellar phases. Table S1 (see Supplementary material) summarizes the repeat distances (d) of GL/POPC mixtures.

Glycosides inserted into the POPC bilayer decrease $d$ : $\Delta d=d_{P O P C} d_{G L / P O P C} \sim 0.4-3.3 \AA$ (Fig. 2, C). Fig. 2A shows SAXS patterns of 11/POPC, where the change of $d$ is the highest one: $\Delta d=d_{P O P C^{-}} d_{11 / P O P C}=65.3-62.0=3.3 \AA$ at $\quad 11 / \mathrm{POPC}=0.2 \mathrm{~mol} /$ mol. However, the highest content of $\mathbf{1 1}$ in POPC bilayer $(11 / \mathrm{POPC}=0.5 \mathrm{~mol} / \mathrm{mol})$ induces a smaller change of $d, \Delta d=2.5 \AA$. Generally, $d$ values of zwitterionic phosphatidylcholines in the $\mathrm{L}_{a}$ state do not exceed $\sim 65-67 \AA$ [16]. $d$ is the sum $d=d_{L}+d_{w}$, where $d_{L}$ is the thickness of the lipid bilayer and $d_{w}$ is the thickness of the water layer between two neighboring lipid bilayers. For zwitterionic phosphatidylcholines, the thickness $d_{w} \sim 1.8-2 \mathrm{~nm}$ is the result of the balance between repulsive interbilayer interactions (steric, hydration and fluctuations) and attractive van der Waals forces [16]. Thus, changes of both thicknesses, the lipid bilayer $\left(d_{L}\right)$ as well as the water layer $\left(d_{w}\right)$, can contribute to the detected $\Delta d$. Detailed inspection of data in Table $\mathrm{S} 1$ reveals that $\Delta d$ induced by the glycoside alkyl aglycone ( $n=$ number of carbon atoms in aglycone alkyl chain, $n=14$ or 16 ) is larger for $n=14$ Actually, in- duced changes can be quantified in the order glucosides $>$ galacto $\approx$ manno (as it is summarised in Fig. 2, C). POPC molecule is formed by two acyl chains, one saturated palmitic acid $(n=16)$, the other monounsaturated oleic acid ( $n=18,1$ double bond). The length of the glycoside alkyl aglycone with $n=16$ fits well inside the hydrophobic POPC region, creating smaller disturbance than the glycoside with $n=14$. The studied glycosides are nonionic compounds and their molecules differ in the stereochemical arrangement of hydroxyl groups attached to a tetrahydropyrane ring. In the bilayer, the hydrophilic part of the glycoside, localized in the polar region of POPC, causes a lateral expansion of the bilayer that, in synergy with the hydrophobic mismatch between POPC and tetradecyl aglycone, explains the decrease of the lipid bilayer thickness $\left(d_{L}\right)$. Thus, we attribute $\Delta d$ by changes of the lipid bilayer thickness $\left(d_{L}\right)$. Our results indicate small differences in localization of glycoside in the POPC bilayer due to the stereochemical arrangement of hydroxyl groups. The asymmetry of the peak (second order reflection, L2) in the pattern of 18/POPC $=0.5 \mathrm{~mol} /$ mol (Fig. 2, A, marked by an arrow) indicates a phase separation in the mixture. Another lamellar phase was detected with repeat distance $d=64.0 \pm 0.22 \AA$. Similar structural changes were observed in mixtures with the highest amount of 4 in the bilayer $(0.5 \mathrm{~mol} / \mathrm{mol})$ (Fig. $2 \mathrm{~B})$. Higher temperature promotes a phase separation as it is clearly seen for $4 / \mathrm{POPC}=0.5 \mathrm{~mol} / \mathrm{mol}$ at $60^{\circ} \mathrm{C}$. The pattern was fitted assuming the superposition of two coexisting lamellar phases. Dashed lines show individual peaks $\left(\mathrm{L} 1_{\mathrm{a}}, \mathrm{L} 1_{\mathrm{b}}\right.$, etc.). Two phases $\left(\mathrm{L}_{\mathrm{a}}\right.$ and $\left.\mathrm{L}_{\mathrm{b}}\right)$ with periodicities $d_{a}=65.3 \pm 0.13 \AA$ and $d_{b}=61.5 \pm 0.23 \AA$ indicate absence of ideal mixing of the glycoside with the lipid. It was identified that $\mathrm{L}_{\mathrm{a}}$ is a phase rich of POPC, likely with a low content of $4\left(d_{a} \sim d_{P O P C}\right)$, while a phase $\mathrm{L}_{\mathrm{b}}$, has a higher amount of 4 $\left(d_{b}<d_{P O P C}\right)$. $d$ of fully hydrated POPC bilayers increases $\sim 2 \AA$ in the temperature range $25-60{ }^{\circ} \mathrm{C}$ [14]. Glycosidic surfactants with alkyl aglycone (C14-C16) and their interactions with lipid mem-

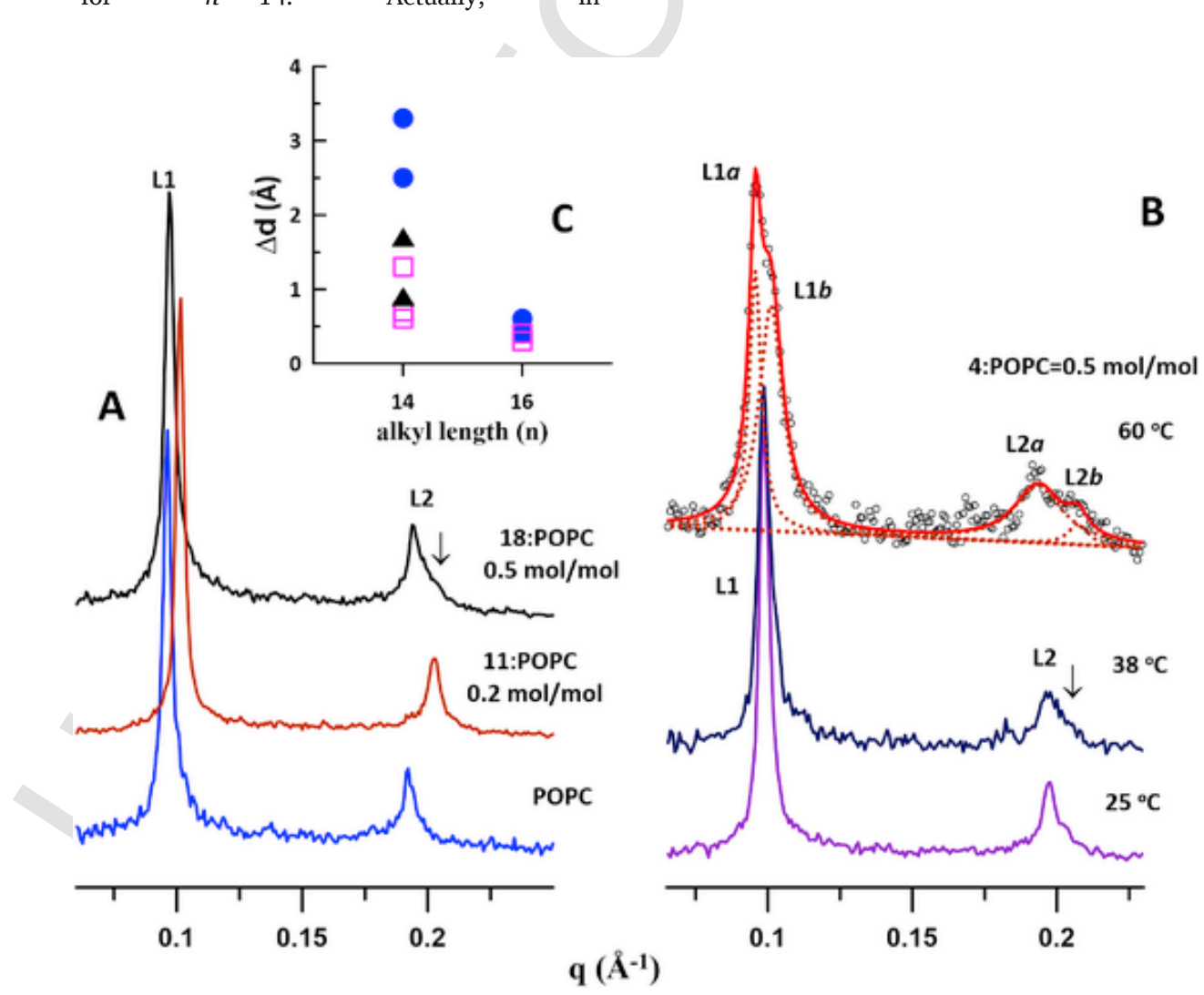

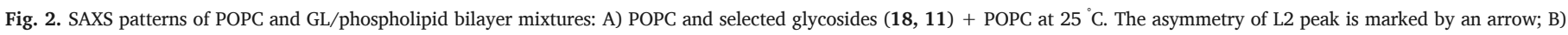

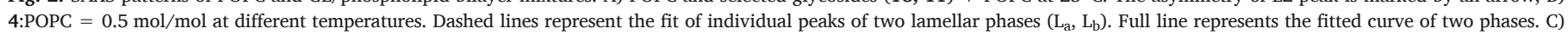
$\Delta d=d_{P O P C}-d_{G L / P O P C}$ as a function of the length $n$ of alkyl aglycone of GL: gluco- (full circles); galacto- (empty squares) and manno- (full triangles). 
branes are rarely discussed. In accord with our findings, Carion-Taravella et al. [17] reported the reduction of the lipid bilayer thickness of saturated dipalmitoylphosphatidylcholine (DPPC) due to its interaction with dodecyl- $\beta$-D-glucopyranoside, and coexistence of lamellar phases.

In summary, we did not observe changes of the long-range organization of POPC bilayer in presence of glycosides, meaning that the lamellar phase was preserved in all studied mixtures. Instead, SAXS experiments revealed that glycosides affect the structure of the POPC membrane, changing the lipid bilayer thickness. High glycoside content induces lateral phase separation resulting in two phases $\left(\mathrm{L}_{\mathrm{a}}, \mathrm{L}_{\mathrm{b}}\right)$ with slightly different periodicities, although without macroscopic phase separation. The small difference between the two repeat distances supports the model of coexistence of two phases within one supramolecular structure, which can be due to non-ideal mixing of compounds. Lipid components of biological membranes are not uniformly distributed in the membrane, they create domains. Experiments have shown that glycosides can alter this distribution by their clustering with neutral phospholipids, main component of the membrane. This can be toxic for the cell either by preventing the interaction of lipids with other membrane components, or by disrupting existing natural domains. Finally, we found that even minor amounts of glycosides affect the lipid bilayer thickness which plays a crucial role in the activity of transmembrane proteins [18].

\section{Conclusions}

It is known that lipophilicity of the compounds plays an important role in their penetration into cells and in cell permeability. The length of aglycone is a factor determining lipophilicity of the investigated nonionic alkyl glycosides. The most lipophilic ones show the highest cytotoxicity, but this dependence was not clear for all tested cancer cell lines. In addition, the most lipophilic mannosides also do affect negatively non-tumor lines, what is a serious limitation for their use as anticancer drugs. The most lipophilic glycosides are not the strongest antibacterials, but, in some cases, their selectivity against different bacterial strains depends on the length of the aglycone chain.

Among the 19 tested sugar based amphiphiles, we identified those specific for eukaryotes.

Tetradecyl $\beta$-D-galactopyranoside (18) shows the most promising cytotoxicity and the highest TI (9.1) against CCRF-CEM cancer cell line. At higher concentrations $\left(5 \times \mathrm{IC}_{50}\right)$, we observe the accumulation of the cells in G0/G1 cell phase and inhibition of DNA/RNA synthesis, which can be a non-specific phenotype of the pre-/apoptotic cells. Along with hexadecyl $\beta$-D-galactopyranoside (19) having TI (4.2, CCRF-CEM), these two glycolipids have no antimicrobial activity. Therefore, they could be a target specific for eukaryotic cells.

Regarding prokaryotes, tetradecyl and hexadecyl $\beta$-D-glucopyranosides (11) and (12) are selective inhibitors of $E$. faecalis. The Candida sp. strains were sensitive only to glycosides having (thio)dodecyl aglycone, which are the broadest spectrum antimicrobials inhibiting enterococci as well as staphylococci.

The structural study reveals small but not negligible changes in the lipid bilayer from zwitterionic POPC induced by glycosides selected for these pilot experiments. However, the detected "mild effect" can generate lateral disorder in membrane components resulting in malfunction of the cell. On the other hand, long-range order in lamellar phase is preserved up to rather high content of the additive in the lipid bilayer. Therefore, the antimicrobial activity is not due to membrane fragmentation and formation of non-lamellar phases, as often observed with antimicrobial peptides [19]. On another hand, one can take advantage of this "mild effect" when designing a lipid-based carrier for glycosides at targeted drug delivery.

The results presented in this study reveal an interesting potential of nonionic glycosides. This is in line with recent demands for bioactive compounds, which are strongly preferred because based on natural ori- gin, contrary to synthetic compounds. The tested glycosides fulfill these trends for bioprotection, since the combination of saccharides with lipids, two biodegradable components, fully meet the requirements for nature-like composition. Therefore, the active glycolipid mimetic should become an environmentally friendly alternative to common products.

\section{Experimental}

\subsection{General}

TLC was performed on aluminum sheets precoated with silica gel 60 $\mathrm{F}_{254}$ (Merck). Flash column chromatography was carried out on silica gel 60 (0.040-0.060 mm, Merck) with distilled solvents (hexanes, ethyl acetate, methanol). Dry dichloromethane and dry 1,2-dichloroethane were purchased from Aldrich. POPC (1-palmitoyl-2-oleoyl-glycero-3-phosphocholine) was purchased from Avanti Polar Lipids, Inc., USA. All reactions containing sensitive reagents were carried out under an argon atmosphere. ${ }^{1} \mathrm{H}$ NMR and ${ }^{13} \mathrm{C}$ NMR spectra were recorded at $25{ }^{\circ} \mathrm{C}$ with Bruker AVANCE III HD 400 spectrometer. Chemical shifts are referenced to either TMS $\left(\delta 0.00, \mathrm{CDCl}_{3}\right.$ for $\left.{ }^{1} \mathrm{H}\right)$ or $\mathrm{HOD}\left(\delta 4.87, \mathrm{CD}_{3} \mathrm{OD}\right.$ for $\left.{ }^{1} \mathrm{H}\right)$, and to internal $\mathrm{CDCl}_{3}(\delta 77.00)$ or $\mathrm{CD}_{3} \mathrm{OD}(\delta 49.00)$ for ${ }^{13} \mathrm{C}$. Optical rotations were measured on a Jasco $\mathrm{P} 2000$ polarimeter at $20{ }^{\circ} \mathrm{C}$. High-resolution mass determination was performed by ESI-MS on a Thermo Scientific Orbitrap Exactive instrument operating in positive mode.

All the tested compounds used in biological tests were lyophilized before the use. Peracetylated donors were synthesized according to published procedure [20].

\subsection{General procedure for glycosylation}

A stirred solution containing peracetylated donor $(1 \mathrm{~g}, 2.56 \mathrm{mmol}, 1$ eq) in dry solvent $\left(10 \mathrm{~mL}\right.$ ) was cooled down on an ice bath and $\mathrm{BF}_{3} \cdot \mathrm{OEt}_{2}$ was added. After being stirred for $10 \mathrm{~min}$, the corresponding alcohol (1.5 eq) was added dropwise. Then the resulting mixture was stirred at $\mathrm{rt}$. The reaction mixture was then diluted with solvent $(50 \mathrm{~mL})$ and poured into ice cold satd $\mathrm{NaHCO}_{3}(100 \mathrm{~mL})$ under stirring. The organic phase was separated, washed with water $(100 \mathrm{~mL})$, dried with anhydrous $\mathrm{Na}_{2} \mathrm{SO}_{4}$, filtered and concentrated. The crude product was purified by flash chromatography (Hexane:EtOAc 7:1 $\rightarrow 3: 1$ ).

The conditions (catalyst, solvent, reaction time) used in the synthesis of acetylated glycosides: $\beta$-C10 glycosides $6 \mathbf{a}$ and $13 \mathrm{a}: \mathrm{BF}_{3} \cdot \mathrm{OEt}_{2}$ (5eq), DCM, 5 h; $\alpha / \beta$ C12 glycosides 7a, 8a, 14a, 15a: BF $3 . \mathrm{OEt}_{2}$ (5eq), DCM, $24 \mathrm{~h} ; \alpha / \beta$ SC12 glycosides 9a, 10a, 16a, 17a: $\mathrm{BF}_{3} \cdot \mathrm{OEt}_{2}$ (1.5 eq), DCE, $5 \mathrm{~h} ; \beta$-C14 glycosides 11a and 18a: $\mathrm{BF}_{3} \cdot \mathrm{OEt}_{2}$ (3eq), DCE, $22 \mathrm{~h} ; \beta-\mathrm{C} 16$ glycosides 12a and 19a: $\mathrm{BF}_{3} \cdot \mathrm{OEt}_{2}$ (3eq), DCE, $22 \mathrm{~h}$.

\subsection{General procedure for deprotection}

To a solution of peracetylated glycoside (1eq) in $\mathrm{MeOH}(9.5 \mathrm{~mL})$ MeONa ( $1 \mathrm{M}, 0.50 \mathrm{~mL}$ ) was added. The reaction mixture was stirred for $16 \mathrm{~h}$, neutralized with Dowex $50 \mathrm{H}^{+}$-form and filtered. After removal of the solvent, the residue was purified by column chromatography (hexane:EtOAc 1:9 $\rightarrow$ EtOAc $\rightarrow$ EtOAc: $\mathrm{MeOH}$ 10:1).

\subsubsection{Tetradecyl 2,3,4,6-tetra-O-acetyl- $\alpha$-D-mannopyranoside (4a)}

Synthesis was carried out as reported previously [6]. Yield $0.82 \mathrm{~g}$, $59 \%$, clear oil. $[\alpha]_{\mathrm{D}}+23.3\left(\mathrm{c} 0.5, \mathrm{CHCl}_{3}\right) .{ }^{1} \mathrm{H}$ NMR (400 MHz, $\left.\mathrm{CDCl}_{3}\right)$ : $\delta 5.37\left(\mathrm{dd}, 1 \mathrm{H}, J_{2,3}=3.4 \mathrm{~Hz}, \mathrm{H}-3\right), 5.29\left(\mathrm{dd}, 1 \mathrm{H}, J_{3,4}=9.9 \mathrm{~Hz}\right.$, $\left.J_{4,5}=9.8 \mathrm{~Hz}, \mathrm{H}-4\right), 5.23$ (dd, $\left.1 \mathrm{H}, \mathrm{H}-2\right), 4.81$ (d, $1 \mathrm{H}, J_{1,2}=1.7 \mathrm{~Hz}$, $\mathrm{H}-1$ ), 4.29 (dd, $1 \mathrm{H}, J_{5,6 \mathrm{~b}}=5.3 \mathrm{~Hz}, J_{6 \mathrm{a}, 6 \mathrm{~b}}=12.1 \mathrm{~Hz}, \mathrm{H}-6 \mathrm{~b}$ ), 4.11 (dd, $1 \mathrm{H}, J_{5,6 \mathrm{a}}=2.4 \mathrm{~Hz}, \mathrm{H}-6 \mathrm{a}$ ), 3.99 (ddd, $1 \mathrm{H}, \mathrm{H}-5$ ), 3.68 (dt, $1 \mathrm{H}$, $\left.J=6.7 \mathrm{~Hz}, J=9.6 \mathrm{~Hz}, \mathrm{OCH}_{2}\left(\mathrm{CH}_{2}\right)_{12} \mathrm{CH}_{3}\right), 3.45(\mathrm{dt}, 1 \mathrm{H}, J=6.5 \mathrm{~Hz}$, $J=9.5 \mathrm{~Hz}, \mathrm{OCH}_{2}\left(\mathrm{CH}_{2}\right)_{12} \mathrm{CH}_{3}$ ), 2.15, 2.10, 2.04, 1.99 (each s, each $3 \mathrm{H}$, 
$\left.4 \times \mathrm{CH}_{3} \mathrm{CO}\right), 1.64-1.24\left(\mathrm{~m}, 24 \mathrm{H}, \mathrm{OCH}_{2}\left(\mathrm{CH}_{2}\right)_{12} \mathrm{CH}_{3}\right), 0.88$ (t, $3 \mathrm{H}$, $\left.J=6.5 \mathrm{~Hz}, \mathrm{O}\left(\mathrm{CH}_{2}\right)_{13} \mathrm{CH}_{3}\right) .{ }^{13} \mathrm{C} \mathrm{NMR}\left(100 \mathrm{MHz}, \mathrm{CDCl}_{3}\right): \delta 170.6,170.1$, 170.0, 169.8 (4× $\mathrm{CH}_{3} \mathrm{CO}$ ), 97.6 (C-1), 69.9 (C-2), 69.2 (C-3), 68.6, $68.5\left(\mathrm{C}-5, \mathrm{OCH}_{2}\left(\mathrm{CH}_{2}\right)_{12} \mathrm{CH}_{3}\right), 66.4$ (C-4), $62.6(\mathrm{C}-6), 32.0,29.8(3 \times)$, $29.7(2 \times), 29.6(2 \times), 29.4,29.3,26.1,22.7\left(\mathrm{OCH}_{2}\left(\mathrm{CH}_{2}\right)_{12} \mathrm{CH}_{3}\right), 20.9$, $20.7(3 \times)\left(4 \times \mathrm{CH}_{3} \mathrm{CO}\right), 14.2\left(\mathrm{O}_{\left(\mathrm{CH}_{2}\right)}{ }_{13} \mathrm{CH}_{3}\right)$. HRMS (ESI) $\mathrm{m} / z$ : calcd for $\mathrm{C}_{28} \mathrm{H}_{48} \mathrm{O}_{10} \mathrm{Na}[\mathrm{M}+\mathrm{Na}]^{+}$: 567.3140 ; found: 567.3135 .

\subsubsection{Decyl 2,3,4,6-tetra-O-acetyl- $\beta$-D-glucopyranoside (6a)}

Yield $0.39 \mathrm{~g}, 31 \%$, clear oil. $[\alpha]_{\mathrm{D}}-16.5$ (c 1.1, $\mathrm{CHCl}_{3}$ ). Analytical data, $[\alpha]_{\mathrm{D}}-15.0$ (c 1.19, $\mathrm{CHCl}_{3}$ ) [21], ${ }^{1} \mathrm{H}$ NMR [22] and ${ }^{13} \mathrm{C}$ NMR [21] data were reported previously. HRMS (ESI) $m / z$ : calcd for $\mathrm{C}_{24} \mathrm{H}_{40} \mathrm{O}_{10} \mathrm{Na}$ $[\mathrm{M}+\mathrm{Na}]^{+}:$511.2514; found: 511.2518 .

\subsubsection{Dodecyl 2,3,4,6-tetra-O-acetyl- $\alpha$-D-glucopyranoside (7a)}

Yield $0.45 \mathrm{~g}, 34 \%$, clear oil. $[\alpha]_{\mathrm{D}}+44.5\left(\mathrm{c} 0.2, \mathrm{CHCl}_{3}\right) .{ }^{1} \mathrm{H} \mathrm{NMR}$ $\left(400 \mathrm{MHz}, \mathrm{CDCl}_{3}\right): \delta 5.48\left(\mathrm{t}, 1 \mathrm{H}, J_{3,4}=9.8 \mathrm{~Hz}, \mathrm{H}-3\right), 5.08-5.03(\mathrm{~m}$, $2 \mathrm{H}, \mathrm{H}-1, \mathrm{H}-4$ ), 4.85 (dd, $1 \mathrm{H}, J_{1,2}=3.7 \mathrm{~Hz}, J_{2,3}=10.2 \mathrm{~Hz}, \mathrm{H}-2$ ), 4.26 $\left(\mathrm{dd}, 1 \mathrm{H}, \quad J_{5,6 \mathrm{~b}}=4.5 \mathrm{~Hz}, \quad J_{6 \mathrm{a}, 6 \mathrm{~b}}=12.4 \mathrm{~Hz}, \mathrm{H}-6 \mathrm{~b}\right), 4.09(\mathrm{dd}, 1 \mathrm{H}$, $\left.J_{5,6 \mathrm{a}}=2.3 \mathrm{~Hz}, \mathrm{H}-6 \mathrm{a}\right), 4.02(\mathrm{~m}, 1 \mathrm{H}, \mathrm{H}-5), 3.67(\mathrm{dt}, 1 \mathrm{H}, J=6.6 \mathrm{~Hz}$, $\left.J=9.9 \mathrm{~Hz}, \mathrm{OCH}_{2}\left(\mathrm{CH}_{2}\right)_{10} \mathrm{CH}_{3}\right), 3.43(\mathrm{dt}, 1 \mathrm{H}, J=6.5 \mathrm{~Hz}, J=9.9 \mathrm{~Hz}$, $\mathrm{OCH}_{2}\left(\mathrm{CH}_{2}\right)_{10} \mathrm{CH}_{3}$ ), 2.09, 2.06, 2.03, 2.01 (each s, each $3 \mathrm{H}, 4 \times \mathrm{CH}_{3} \mathrm{CO}$ ), $1.59-1.26\left(\mathrm{~m}, 20 \mathrm{H}, \mathrm{OCH}_{2}\left(\mathrm{CH}_{2}\right)_{10} \mathrm{CH}_{3}\right), 0.88(\mathrm{t}, 3 \mathrm{H}, J=6.5 \mathrm{~Hz}$, $\left.\mathrm{O}\left(\mathrm{CH}_{2}\right)_{11} \mathrm{CH}_{3}\right) .{ }^{13} \mathrm{C}$ NMR (100 MHz, $\left.\mathrm{CDCl}_{3}\right): \delta 170.7,170.2(2 \times), 169.7$ (4× $\left.\mathrm{CH}_{3} \mathrm{CO}\right), 95.6$ (C-1), 71.0 (C-2), 70.3 (C-3), 68.8, 68.7 (C-4, $\mathrm{OCH}_{2}\left(\mathrm{CH}_{2}\right)_{10} \mathrm{CH}_{3}$ ), 67.1 (C-5), 62.0 (C-6), 31.9, 29.7(2×), 29.6(3×), 29.4, 29.3, 26.1, $22.7\left(\mathrm{OCH}_{2}\left(\mathrm{CH}_{2}\right)_{10} \mathrm{CH}_{3}\right), 20.8(2 \times), 20.7(2 \times)(4 \times$

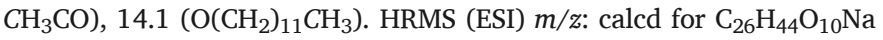
$[\mathrm{M}+\mathrm{Na}]^{+}:$539.2827; found: 539.2829 .

\subsubsection{Dodecyl 2,3,4,6-tetra-O-acetyl- $\beta$-D-glucopyranoside (8a)}

Yield $0.42 \mathrm{~g}, 32 \%$, clear oil. $[\alpha]_{\mathrm{D}}-16.0\left(c 0.5, \mathrm{CHCl}_{3}\right) .{ }^{1} \mathrm{H}$ NMR data were reported [23]. $\left.{ }^{13} \mathrm{C} \mathrm{NMR} \mathrm{(100} \mathrm{MHz}, \mathrm{CDCl}_{3}\right): \delta 170.7,170.4,169.5$, $169.3\left(4 \times \mathrm{CH}_{3} \mathrm{CO}\right.$ ), 100.9 (C-1), 73.0 (C-3), 71.8 (C-5), 71.5 (C-2), $70.4\left(\mathrm{OCH}_{2}\left(\mathrm{CH}_{2}\right)_{10} \mathrm{CH}_{3}\right), 68.6$ (C-4), 62.1 (C-6), 32.0, 29.8, 29.7(3×), 29.5, 29.4(2×), 25.9, $22.8\left(\mathrm{OCH}_{2}\left(\mathrm{CH}_{2}\right)_{10} \mathrm{CH}_{3}\right), 20.8,20.7(3 \times)(4 \times$ $\left.\mathrm{CH}_{3} \mathrm{CO}\right), 14.2\left(\mathrm{O}_{\left(\mathrm{CH}_{2}\right)}{ }_{11} \mathrm{CH}_{3}\right)$. HRMS (ESI) $\mathrm{m} / \mathrm{z}$ : calcd for $\mathrm{C}_{26} \mathrm{H}_{44} \mathrm{O}_{10} \mathrm{Na}$ $[\mathrm{M}+\mathrm{Na}]^{+}$: 539.2827; found: 539.2823 .

\subsubsection{Dodecyl 2,3,4,6-tetra-O-acetyl-1-thio- $\alpha$-D-glucopyranoside (9a)}

Yield 0.16 g, $12 \%$, yellowish oil. $[\alpha]_{\mathrm{D}}+120.0\left(\mathrm{c} 0.25, \mathrm{CHCl}_{3}\right) .{ }^{1} \mathrm{H}$ NMR (400 MHz, $\mathrm{CDCl}_{3}$ ): $\delta 5.61$ (d, $\left.1 \mathrm{H}, J_{1,2}=5.8 \mathrm{~Hz}, \mathrm{H}-1\right), 5.32$ (dd, $\left.1 \mathrm{H}, J_{4,5}=9.7 \mathrm{~Hz}, \mathrm{H}-4\right), 5.01\left(\mathrm{dd}, 1 \mathrm{H}, J_{3,4}=9.7 \mathrm{~Hz}, \mathrm{H}-3\right), 4.98$ (dd, $\left.1 \mathrm{H}, J_{2,3}=10.2 \mathrm{~Hz}, \mathrm{H}-2\right), 4.39$ (ddd, $1 \mathrm{H}, J_{5,6 \mathrm{a}}=2.3 \mathrm{~Hz}, J_{5,6 \mathrm{~b}}=4.7 \mathrm{~Hz}$, H-5), $4.26\left(\mathrm{dd}, 1 \mathrm{H}, J_{6 \mathrm{a}, 6 \mathrm{~b}}=12.3 \mathrm{~Hz}, \mathrm{H}-6 \mathrm{~b}\right), 4.02$ (dd, $\left.1 \mathrm{H}, \mathrm{H}-6 \mathrm{a}\right)$, 2.55-2.41 (m, $2 \mathrm{H}, \mathrm{SCH}_{2}\left(\mathrm{CH}_{2}\right)_{10} \mathrm{CH}_{3}$ ), 2.04, 2.02, 2.00, 1.97 (each s, each $\left.3 \mathrm{H}, 4 \times \mathrm{CH}_{3} \mathrm{CO}\right), 1.58-1.19\left(\mathrm{~m}, 20 \mathrm{H}, \mathrm{SCH}_{2}\left(\mathrm{CH}_{2}\right)_{10} \mathrm{CH}_{3}\right), 0.83$ (t, $\left.3 \mathrm{H}, J=6.6 \mathrm{~Hz}, \mathrm{~S}\left(\mathrm{CH}_{2}\right)_{11} \mathrm{CH}_{3}\right) .{ }^{13} \mathrm{C} \mathrm{NMR}\left(100 \mathrm{MHz}, \mathrm{CDCl}_{3}\right): \delta 170.7$, $170.4,170.3,169.9\left(4 \times \mathrm{CH}_{3} \mathrm{CO}\right), 81.8$ (C-1), 70.6 (C-2), 70.2 (C-4), 68.5 (C-3), 67.3 (C-5), 62.6 (C-6), $30.3\left(\mathrm{SCH}_{2}\left(\mathrm{CH}_{2}\right)_{10} \mathrm{CH}_{3}\right), 32.0,30.0$, $29.7(2 \times), 29.6(2 \times), 29.5,29.4,28.9,22.7 \quad\left(\mathrm{SCH}_{2}\left(\mathrm{CH}_{2}\right)_{10} \mathrm{CH}_{3}\right)$, $20.6(2 \times), 20.5(2 \times)\left(4 \times \mathrm{CH}_{3} \mathrm{CO}\right), 14.2\left(\mathrm{~S}\left(\mathrm{CH}_{2}\right)_{11} \mathrm{CH}_{3}\right)$. HRMS (ESI) $\mathrm{m} /$ z: calcd for $\mathrm{C}_{26} \mathrm{H}_{44} \mathrm{O}_{9} \mathrm{SNa}[\mathrm{M}+\mathrm{Na}]^{+}:$555.2598; found: 555.2596 .

\subsubsection{Dodecyl 2,3,4,6-tetra-O-acetyl-1-thio- $\beta$-D-glucopyranoside (10a)}

Yield $0.70 \mathrm{~g}, 38 \%$, yellowish oil. $[\alpha]_{\mathrm{D}}-28.0\left(\mathrm{c} 0.15, \mathrm{CHCl}_{3}\right)$. Analytical data, $[\alpha]_{\mathrm{D}}{ }^{20}-29.2\left(\mathrm{c} 0.12, \mathrm{CHCl}_{3}\right)[24],{ }^{1} \mathrm{H}$ and ${ }^{13} \mathrm{C}$ NMR [25] data were reported. HRMS (ESI) $m / z$ : calcd for $\mathrm{C}_{26} \mathrm{H}_{44} \mathrm{O}_{9} \mathrm{SNa}[\mathrm{M}+\mathrm{Na}]^{+}$: 555.2598; found: 555.2593 .

\subsubsection{Tetradecyl 2,3,4,6-tetra-O-acetyl- $\beta$-D-glucopyranoside (11a)}

Yield $0.49 \mathrm{~g}, 35 \%$, white solid. $[\alpha]_{\mathrm{D}}-29.4\left(c \mathrm{0.5}, \mathrm{CHCl}_{3}\right)$. Analytical data, $[\alpha]_{\mathrm{D}}{ }^{20}-63.8\left(c 0.2, \mathrm{CHCl}_{3}\right)[26],{ }^{1} \mathrm{H}$ and ${ }^{13} \mathrm{C}$ NMR data were re- ported [27]. HRMS (ESI) $m / z$ : calcd for $\mathrm{C}_{28} \mathrm{H}_{48} \mathrm{O}_{10} \mathrm{Na}[\mathrm{M}+\mathrm{Na}]^{+}$: 567.3140; found: 567.3143 .

\subsubsection{Hexadecyl 2,3,4,6-tetra-O-acetyl- $\beta$-D-glucopyranoside (12a)}

Yield $0.56 \mathrm{~g}, 38 \%$, white solid. $[\alpha]_{\mathrm{D}}-18.0\left(\mathrm{c} 0.5, \mathrm{CHCl}_{3}\right) .{ }^{1} \mathrm{H}$ and ${ }^{13} \mathrm{C}$ NMR data were reported [27]. HRMS (ESI) $m / z$ : calcd for $\mathrm{C}_{30} \mathrm{H}_{52} \mathrm{O}_{10} \mathrm{Na}$ $[\mathrm{M}+\mathrm{Na}]^{+}$: 595.3453; found: 595.3445 .

\subsubsection{Decyl 2,3,4,6-tetra-O-acetyl- $\beta$-D-galactopyranoside (13a)}

Yield $0.40 \mathrm{~g}, 32 \%$, clear oil. $[\alpha]_{\mathrm{D}}-15.6$ (c 1.1, $\mathrm{CHCl}_{3}$ ). Analytical data, $[\alpha]_{\mathrm{D}}{ }^{20}-11.6\left(c\right.$ 1.5, $\left.\mathrm{CHCl}_{3}\right)[22],{ }^{1} \mathrm{H}$ NMR data were reported [8]. ${ }^{13} \mathrm{C} \mathrm{NMR}\left(100 \mathrm{MHz}, \mathrm{CDCl}_{3}\right): \delta 170.5,170.4,170.3,169.5(4 \times$ $\mathrm{CH}_{3} \mathrm{CO}$ ), 101.5 (C-1), 71.1 (C-3), 70.7 (C-5), $70.5\left(\mathrm{OCH}_{2}\left(\mathrm{CH}_{2}\right)_{8} \mathrm{CH}_{3}\right)$, 69.1 (C-2), 67.2 (C-4), 61.4 (C-6), 32.0, 29.7(2×), 29.6, 29.5(2×), 26.0, $22.8\left(\mathrm{OCH}_{2}\left(\mathrm{CH}_{2}\right)_{8} \mathrm{CH}_{3}\right), 20.9,20.8(2 \times), 20.7\left(4 \times \mathrm{CH}_{3} \mathrm{CO}\right), 14.3$ $\left(\mathrm{O}\left(\mathrm{CH}_{2}\right)_{9} \mathrm{CH}_{3}\right)$. HRMS (ESI) $\mathrm{m} / z$ : calcd for $\mathrm{C}_{24} \mathrm{H}_{40} \mathrm{O}_{10} \mathrm{Na}[\mathrm{M}+\mathrm{Na}]^{+}$: 511.2514; found: 511.2513 .

\subsubsection{Dodecyl 2,3,4,6-tetra-O-acetyl- $\alpha$-D-galactopyranoside (14a)}

Yield $0.29 \mathrm{~g}, 22 \%$, white semisolid. $[\alpha]_{\mathrm{D}}+10.0\left(c 0.5, \mathrm{CHCl}_{3}\right) .{ }^{1} \mathrm{H}$ NMR data were reported [8]. ${ }^{13} \mathrm{C}$ NMR $\left(100 \mathrm{MHz}, \mathrm{CDCl}_{3}\right): \delta 170.4$, $170.3(2 \times), 170.0\left(4 \times \mathrm{CH}_{3} \mathrm{CO}\right), 96.2(\mathrm{C}-1), 68.7\left(\mathrm{OCH}_{2}\left(\mathrm{CH}_{2}\right)_{10} \mathrm{CH}_{3}\right)$, 68.3, 68.2 (C-3, C-4), 67.7 (C-2), 66.2 (C-5), 61.9 (C-6), 32.0, 29.7(3×), $29.6(2 \times), 29.4(2 \times), 26.2,22.7\left(\mathrm{OCH}_{2}\left(\mathrm{CH}_{2}\right)_{10} \mathrm{CH}_{3}\right), 20.8,20.7(3 \times)$

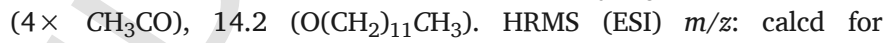
$\mathrm{C}_{26} \mathrm{H}_{44} \mathrm{O}_{10} \mathrm{Na}[\mathrm{M}+\mathrm{Na}]^{+}$: 539.2827; found: 539.2833.

4.3.11. Dodecyl 2,3,4,6-tetra-O-acetyl- $\beta$-D-galactopyranoside (15a)

Yield $0.40 \mathrm{~g}, 30 \%$, white solid. $[\alpha]_{\mathrm{D}}-10.0\left(\mathrm{c} 0.5, \mathrm{CHCl}_{3}\right)$. Analytical data, $[\alpha]_{\mathrm{D}}{ }^{25}-14.0\left(c 0.8, \mathrm{CHCl}_{3}\right)[28]$ and ${ }^{1} \mathrm{H}$ NMR data were reported [23]. ${ }^{13} \mathrm{C}$ NMR (100 MHz, $\left.\mathrm{CDCl}_{3}\right): \delta 170.5,170.4,170.2,169.4(4 \times$ $\mathrm{CH}_{3} \mathrm{CO}$ ), 101.4 (C-1), 71.1 (C-3), 70.76 (C-5), $70.4\left(\mathrm{OCH}_{2}\left(\mathrm{CH}_{2}\right)_{10} \mathrm{CH}_{3}\right)$, 69.1 (C-2), 67.2 (C-4), 61.4 (C-6), 32.0, 29.7(3×), 29.5(2×), 29.4(2×), 25.9, $22.8\left(\mathrm{OCH}_{2}\left(\mathrm{CH}_{2}\right)_{10} \mathrm{CH}_{3}\right), 20.8,20.7(3 \times)\left(4 \times \mathrm{CH}_{3} \mathrm{CO}\right), 14.3$ $\left(\mathrm{O}\left(\mathrm{CH}_{2}\right)_{11} \mathrm{CH}_{3}\right)$. HRMS (ESI) $\mathrm{m} / z$ : calcd for $\mathrm{C}_{26} \mathrm{H}_{44} \mathrm{O}_{10} \mathrm{Na}[\mathrm{M}+\mathrm{Na}]^{+}$: 539.2827; found: 539.2831 .

4.3.12. Dodecyl 2,3,4,6-tetra-O-acetyl-1-thio- $\alpha$-D-galactopyranoside (16a)

Yield $0.17 \mathrm{~g}, 12 \%$, yellowish oil. $[\alpha]_{\mathrm{D}}+144.0\left(\mathrm{c} 0.5, \mathrm{CHCl}_{3}\right) .{ }^{1} \mathrm{H}$ NMR (400 MHz, $\mathrm{CDCl}_{3}$ ): $\delta 5.71$ (d, $1 \mathrm{H}, J_{1,2}=5.2 \mathrm{~Hz}, \mathrm{H}-1$ ), 5.45 (dd, $\left.1 \mathrm{H}, J_{4,5}=1.3 \mathrm{~Hz}, \mathrm{H}-4\right), 5.26$ (dd, $1 \mathrm{H}, J_{2,3}=10.8 \mathrm{~Hz}, \mathrm{H}-2$ ), 5.22 (dd, $\left.1 \mathrm{H}, J_{3,4}=10.8 \mathrm{~Hz}, \mathrm{H}-3\right), 4.60-4.57(\mathrm{~m}, 1 \mathrm{H}, \mathrm{H}-5), 4.14-4.06(\mathrm{~m}, 2 \mathrm{H}$, H-6a, H-6b), 2.60-2.45 (m, 2H, SCH$\left.\left(\mathrm{CH}_{2}\right)_{10} \mathrm{CH}_{3}\right), 2.14,2.07,2.04,1.99$ (each s, each $3 \mathrm{H}, 4 \times \mathrm{CH}_{3} \mathrm{CO}$ ), $1.53-1.25\left(\mathrm{~m}, 20 \mathrm{H}, \mathrm{SCH}_{2}\left(\mathrm{CH}_{2}\right)_{10} \mathrm{CH}_{3}\right.$ ), 0.87 (t, $\left.\left.3 \mathrm{H}, J=6.5 \mathrm{~Hz}, \mathrm{~S}\left(\mathrm{CH}_{2}\right)_{11} \mathrm{CH}_{3}\right) .{ }^{13} \mathrm{C} \mathrm{NMR} \mathrm{(100} \mathrm{MHz,} \mathrm{CDCl}_{3}\right)$ : $\delta 170.5,170.3(2 \times), 170.0\left(4 \times \mathrm{CH}_{3} \mathrm{CO}\right), 82.3(\mathrm{C}-1), 68.3,68.2(2 \times)$ (C-2, C-3, C-4), 66.6 (C-5), 62.0 (C-6), $32.1\left(\mathrm{SCH}_{2}\left(\mathrm{CH}_{2}\right)_{10} \mathrm{CH}_{3}\right), 30.0$, $29.8(2 \times), 29.7(2 \times), 29.5,29.3,29.1,26.1,22.8\left(\mathrm{SCH}_{2}\left(\mathrm{CH}_{2}\right)_{10} \mathrm{CH}_{3}\right)$,

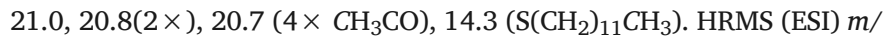
z: calcd for $\mathrm{C}_{26} \mathrm{H}_{44} \mathrm{O}_{9} \mathrm{SNa}[\mathrm{M}+\mathrm{Na}]^{+}$: 555.2598; found: 555.2601.

\subsubsection{Dodecyl 2,3,4,6-tetra-O-acetyl-1-thio- $\beta$-D-galactopyranoside (17a)}

Yield $0.50 \mathrm{~g}, 37 \%$, white solid. $[\alpha]_{\mathrm{D}}-8.0\left(\mathrm{c} 0.5, \mathrm{CHCl}_{3}\right)$. Analytical data, $[\alpha]_{\mathrm{D}}{ }^{20}-16.0\left(c 0.3, \mathrm{CHCl}_{3}\right)[24],{ }^{1} \mathrm{H}$ and ${ }^{13} \mathrm{C}$ NMR data were reported [29]. HRMS (ESI) $m / z$ : calcd for $\mathrm{C}_{26} \mathrm{H}_{44} \mathrm{O}_{9} \mathrm{SNa}[\mathrm{M}+\mathrm{Na}]^{+}$: 555.2598; found: 555.2600 .

\subsubsection{Tetradecyl 2,3,4,6-tetra-O-acetyl- $\beta$-D-galactopyranoside (18a)}

Yield $0.39 \mathrm{~g}, 28 \%$, white solid. $[\alpha]_{\mathrm{D}}-35.7\left(c 0.5, \mathrm{CHCl}_{3}\right) .{ }^{1} \mathrm{H} \mathrm{NMR}$ data were reported [23]. ${ }^{13} \mathrm{C}$ NMR $\left(100 \mathrm{MHz}, \mathrm{CDCl}_{3}\right): \delta 170.5,170.4$, 170.3, 169.5 (4× $\mathrm{CH}_{3} \mathrm{CO}$ ), 101.5 (C-1), 71.1 (C-3), 70.7 (C-5), 70.5 $\left(\mathrm{OCH}_{2}\left(\mathrm{CH}_{2}\right)_{12} \mathrm{CH}_{3}\right), 69.1$ (C-2), 67.2 (C-4), $61.4(\mathrm{C}-6), 32.1,29.8(4 \times)$, $29.6(2 \times), 29.5(3 \times), 26.0,22.8\left(\mathrm{OCH}_{2}\left(\mathrm{CH}_{2}\right)_{12} \mathrm{CH}_{3}\right), 20.9,20.8(2 \times)$, 
20.7 (4 $\left.\times \mathrm{CH}_{3} \mathrm{CO}\right), 14.3\left(\mathrm{O}\left(\mathrm{CH}_{2}\right)_{13} \mathrm{CH}_{3}\right)$. HRMS (ESI) $\mathrm{m} / z$ : calcd for $\mathrm{C}_{28} \mathrm{H}_{48} \mathrm{O}_{10} \mathrm{Na}[\mathrm{M}+\mathrm{Na}]^{+}$: 567.3140; found: 567.3138 .

\subsubsection{Hexadecyl 2,3,4,6-tetra-O-acetyl- $\beta$-D-galactopyranoside (19a)}

Yield $0.29 \mathrm{~g}, 20 \%$, white solid. $[\alpha]_{\mathrm{D}}-22.8\left(\mathrm{c} 0.5, \mathrm{CHCl}_{3}\right) .{ }^{1} \mathrm{H} \mathrm{NMR}$ data were reported [8]. ${ }^{13} \mathrm{C}$ NMR $\left(100 \mathrm{MHz}, \mathrm{CDCl}_{3}\right)$ : $\delta 170.5,170.4$, 170.3, 169.5 (4× $\mathrm{CH}_{3} \mathrm{CO}$ ), 101.5 (C-1), 71.1 (C-3), 70.7 (C-5), 70.5 $\left(\mathrm{OCH}_{2}\left(\mathrm{CH}_{2}\right)_{14} \mathrm{CH}_{3}\right), 69.1$ (C-2), $67.2(\mathrm{C}-4), 61.4$ (C-6), 32.1, 29.9,

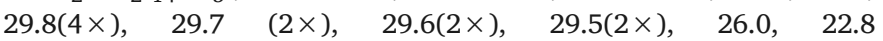
$\left(\mathrm{OCH}_{2}\left(\mathrm{CH}_{2}\right)_{14} \mathrm{CH}_{3}\right), \quad 20.9, \quad 20.8(2 \times), \quad 20.7 \quad\left(4 \times \quad \mathrm{CH}_{3} \mathrm{CO}\right), \quad 14.3$

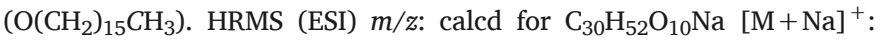
595.3453; found: 595.3456.

Synthesis and analytical data for compounds 1 [13], 2 [6], 3 [13] and 5 [6] were reported.

\subsubsection{Tetradecyl $\alpha$-D-mannopyranoside (4)}

Yield $0.42 \mathrm{~g}, 77 \%$, white solid. $[\alpha]_{\mathrm{D}}+35.6(c$ 0.5, $\mathrm{MeOH})$, ref [30] $[\alpha]_{\mathrm{D}}+50.0\left(c\right.$ 1.0, MeOH). ${ }^{1} \mathrm{H}$ NMR $\left(400 \mathrm{MHz}, \mathrm{CD}_{3} \mathrm{OD}\right): \delta 4.76(\mathrm{~d}$, $\left.1 \mathrm{H}, J_{1,2}=1.7 \mathrm{~Hz}, \mathrm{H}-1\right), 3.86\left(\mathrm{dd}, 1 \mathrm{H}, J_{5,6 \mathrm{a}}=2.4 \mathrm{~Hz}, J_{6 \mathrm{a}, 6 \mathrm{~b}}=11.9 \mathrm{~Hz}\right.$, H-6a), 3.80 (dd, $1 \mathrm{H}, J_{2,3}=3.3 \mathrm{~Hz}, \mathrm{H}-2$ ), 3.77-3.68 (m, 3H, H-3, H-6b, $\mathrm{OCH}_{2}\left(\mathrm{CH}_{2}\right)_{12} \mathrm{CH}_{3}$ ), 3.63 (t, $\left.J_{3,4}=9.5 \mathrm{~Hz}, J_{4,5}=9.5 \mathrm{~Hz}, \mathrm{H}-4\right), 3.56(\mathrm{~m}$, $1 \mathrm{H}, \mathrm{H}-5$ ), 3.44 (dt, $1 \mathrm{H}, J=6.3 \mathrm{~Hz}, J=9.5 \mathrm{~Hz}, \mathrm{OCH}_{2}\left(\mathrm{CH}_{2}\right)_{12} \mathrm{CH}_{3}$ ), 1.65-1.29 (m, 24H, OCH $\left.\left(\mathrm{CH}_{2}\right)_{12} \mathrm{CH}_{3}\right), 0.93$ (t, $3 \mathrm{H}, J=6.6 \mathrm{~Hz}$, $\left.\mathrm{O}\left(\mathrm{CH}_{2}\right)_{13} \mathrm{CH}_{3}\right) .{ }^{13} \mathrm{C}$ NMR (100 MHz, CD $\left.{ }_{3} \mathrm{OD}\right): \delta 101.5$ (C-1), 74.6 (C-5), 72.7 (C-3), $72.3(\mathrm{C}-2), 68.6(2 \times)\left(\mathrm{C}-4, \mathrm{OCH}_{2}\left(\mathrm{CH}_{2}\right)_{12} \mathrm{CH}_{3}\right), 62.9(\mathrm{C}-6)$,

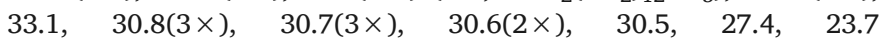
$\left(\mathrm{OCH}_{2}\left(\mathrm{CH}_{2}\right)_{12} \mathrm{CH}_{3}\right), 14.4\left(\mathrm{O}\left(\mathrm{CH}_{2}\right)_{13} \mathrm{CH}_{3}\right)$. HRMS (ESI) $m / z$ : calcd for $\mathrm{C}_{20} \mathrm{H}_{40} \mathrm{O}_{6} \mathrm{Na}[\mathrm{M}+\mathrm{Na}]^{+}$: 399.2917; found: 399.2920.

\subsubsection{Decyl $\beta$-D-glucopyranoside (6)}

Yield $0.20 \mathrm{~g}, 79 \%$, white powder. $[\alpha]_{\mathrm{D}}-35.0$ (c 1.1, MeOH). Analytical data, $[\alpha]_{\mathrm{D}}{ }^{20}-25.4$ (c 1.15, MeOH) [31], ${ }^{1} \mathrm{H}$ and ${ }^{13} \mathrm{C}$ NMR data were reported [32]. HRMS (ESI) $m / z$ : calcd for $\mathrm{C}_{16} \mathrm{H}_{32} \mathrm{O}_{6} \mathrm{Na}[\mathrm{M}+\mathrm{Na}]^{+}$: 343.2091; found: 343.2090 .

\subsubsection{Dodecyl $\alpha$-D-glucopyranoside (7)}

Yield $0.27 \mathrm{~g}, 90 \%$, white powder. $[\alpha]_{\mathrm{D}}+54.5(c 0.9, \mathrm{MeOH})$, ref [31] $[\alpha]_{\mathrm{D}}{ }^{20}+101\left(c\right.$ 1.72, MeOH). ${ }^{1} \mathrm{H}$ NMR $\left(400 \mathrm{MHz}, \mathrm{CD}_{3} \mathrm{OD}\right): \delta$ $4.79\left(\mathrm{~d}, 1 \mathrm{H}, J_{1,2}=3.7 \mathrm{~Hz}, \mathrm{H}-1\right), 3.81\left(\mathrm{dd}, 1 \mathrm{H}, J_{5,6 \mathrm{a}}=2.4 \mathrm{~Hz}\right.$, $\left.J_{6 \mathrm{a}, 6 \mathrm{~b}}=11.9 \mathrm{~Hz}, \quad \mathrm{H}-6 \mathrm{a}\right), 3.75 \quad(\mathrm{dt}, \quad 1 \mathrm{H}, \quad J=6.9 \mathrm{~Hz}, J=9.5 \mathrm{~Hz}$, $\mathrm{OCH}_{2}\left(\mathrm{CH}_{2}\right)_{10} \mathrm{CH}_{3}$ ), 3.69 (dd, $\left.1 \mathrm{H}, J_{5,6 \mathrm{~b}}=5.6 \mathrm{~Hz}, \mathrm{H}-6 \mathrm{~b}\right), 3.66(\mathrm{t}, 1 \mathrm{H}$, $J_{3,4}=9.4 \mathrm{~Hz}, \mathrm{H}-3$ ), 3.59 (ddd, $1 \mathrm{H}, J_{4,5}=9.9 \mathrm{~Hz}, \mathrm{H}-5$ ), $3.46(\mathrm{dt}, 1 \mathrm{H}$, $\left.J=6.5 \mathrm{~Hz}, J=9.6 \mathrm{~Hz}, \mathrm{OCH}_{2}\left(\mathrm{CH}_{2}\right)_{10} \mathrm{CH}_{3}\right), 3.40\left(\mathrm{dd}, 1 \mathrm{H}, J_{2,3}=9.7 \mathrm{~Hz}\right.$, $\mathrm{H}-2$ ), 3.30 (dd, 1H, H-4), 1.69-1.29 (m, 20H, OCH $\left.\left(\mathrm{CH}_{2}\right)_{10} \mathrm{CH}_{3}\right), 0.91$ (t, $\left.3 \mathrm{H}, J=6.8 \mathrm{~Hz}, \mathrm{O}\left(\mathrm{CH}_{2}\right){ }_{11} \mathrm{CH}_{3}\right) \cdot{ }^{13} \mathrm{C}$ NMR $\left(100 \mathrm{MHz}, \mathrm{CD}_{3} \mathrm{OD}\right): \delta 100.1$

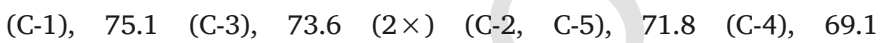
$\left(\mathrm{OCH}_{2}\left(\mathrm{CH}_{2}\right)_{10} \mathrm{CH}_{3}\right), 62.7$ (C-6), 33.1, 30.8(2×), 30.7(3×), 30.6, 30.5, 27.3, $\left.23.7\left(\mathrm{OCH}_{2}\left(\mathrm{CH}_{2}\right)_{10} \mathrm{CH}_{3}\right), 14.4\left(\mathrm{O}_{\left(\mathrm{CH}_{2}\right)}\right)_{11} \mathrm{CH}_{3}\right)$. HRMS (ESI) $\mathrm{m} / z$ : calcd for $\mathrm{C}_{18} \mathrm{H}_{36} \mathrm{O}_{6} \mathrm{Na}[\mathrm{M}+\mathrm{Na}]^{+}$: 371.2404; found: 371.2409 .

\subsubsection{Dodecyl $\beta$-D-glucopyranoside (8)}

Yield $0.24 \mathrm{~g}, 87 \%$, white powder. $[\alpha]_{\mathrm{D}}-26.3$ (c 0.9, MeOH). Analytical data, $[\alpha]_{\mathrm{D}}{ }^{20}-24.1(c$ 1.06, $\mathrm{MeOH})[31],{ }^{1} \mathrm{H}$ and ${ }^{13} \mathrm{C}$ NMR data were reported [32]. HRMS (ESI) $m / z$ : calcd for $\mathrm{C}_{18} \mathrm{H}_{36} \mathrm{O}_{6} \mathrm{Na}[\mathrm{M}+\mathrm{Na}]^{+}$: 371.2404; found: 371.2405 .

\subsubsection{Dodecyl 1-thio- $\alpha$-D-glucopyranoside (9)}

Yield $0.09 \mathrm{~g}, 81 \%$, yellowish powder. $[\alpha]_{\mathrm{D}}^{20}+171.8(c 0.9, \mathrm{MeOH})$, ref $[33][\alpha]_{\mathrm{D}}{ }^{20}+179\left(c\right.$ 1, MeOH). ${ }^{1} \mathrm{H}$ NMR (400 MHz, $\left.\mathrm{CD}_{3} \mathrm{OD}\right): \delta$ $5.33\left(\mathrm{~d}, 1 \mathrm{H}, J_{1,2}=5.4 \mathrm{~Hz}, \mathrm{H}-1\right), 3.97\left(\mathrm{ddd}, 1 \mathrm{H}, J_{4,5}=9.9 \mathrm{~Hz}\right.$, $\left.J_{5,6 \mathrm{~b}}=5.3 \mathrm{~Hz}, \mathrm{H}-5\right), 3.83\left(\mathrm{dd}, 1 \mathrm{H}, J_{5,6 \mathrm{a}}=2.4 \mathrm{~Hz}, J_{6 \mathrm{a}, 6 \mathrm{~b}}=12.0 \mathrm{~Hz}\right.$, H-6a), 3.75-3.68 (m, 2H, H-2, H-6b), 3.55 (t, 1H,
$\left.J_{2,3}=9.3 \mathrm{~Hz}, J_{3,4}=9.3 \mathrm{~Hz}, \mathrm{H}-3\right), 3.33(\mathrm{dd}, 1 \mathrm{H}, \mathrm{H}-4), 2.68-2.55(\mathrm{~m}$, $\left.2 \mathrm{H}, \mathrm{SCH}_{2}\left(\mathrm{CH}_{2}\right)_{10} \mathrm{CH}_{3}\right), 1.68-1.32\left(\mathrm{~m}, 20 \mathrm{H}, \mathrm{SCH}_{2}\left(\mathrm{CH}_{2}\right)_{10} \mathrm{CH}_{3}\right), 0.92$ (t, $\left.3 \mathrm{H}, J=6.8 \mathrm{~Hz}, \mathrm{~S}\left(\mathrm{CH}_{2}\right)_{11} \mathrm{CH}_{3}\right) .{ }^{13} \mathrm{C} \mathrm{NMR}\left(100 \mathrm{MHz}, \mathrm{CD}_{3} \mathrm{OD}\right): \delta 87.2$ (C-1), 75.7 (C-3), 73.9 (C-5), 73.2 (C-2), 71.8 (C-4), 62.6 (C-6), 33.1 $\left(\mathrm{SCH}_{2}\left(\mathrm{CH}_{2}\right)_{10} \mathrm{CH}_{3}\right), 31.1,30.8(3 \times), 30.7(2 \times), 30.5,30.4,30.0,23.7$ $\left(\mathrm{SCH}_{2}\left(\mathrm{CH}_{2}\right)_{10} \mathrm{CH}_{3}\right), 14.4\left(\mathrm{~S}\left(\mathrm{CH}_{2}\right)_{11} \mathrm{CH}_{3}\right)$. HRMS (ESI) $\mathrm{m} / z$ : calcd for $\mathrm{C}_{18} \mathrm{H}_{36} \mathrm{O}_{5} \mathrm{SNa}[\mathrm{M}+\mathrm{Na}]^{+}$: 387.2176; found: 387.2179.

\subsubsection{Dodecyl 1-thio- $\beta$-D-glucopyranoside (10)}

Yield $0.38 \mathrm{~g}, 79 \%$, yellowish powder. $[\alpha]_{\mathrm{D}}{ }^{20}-100.4(c 0.8, \mathrm{MeOH})$. ${ }^{1} \mathrm{H}$ and ${ }^{13} \mathrm{C}$ NMR data were reported [25]. HRMS (ESI) $m / z$ : calcd for $\mathrm{C}_{18} \mathrm{H}_{36} \mathrm{O}_{5} \mathrm{SNa}[\mathrm{M}+\mathrm{Na}]^{+}$: 387.2176; found: 387.2173 .

\subsubsection{Tetradecyl $\beta$-D-glucopyranoside (11)}

Yield $0.28 \mathrm{~g}, 82 \%$, white powder. $[\alpha]_{\mathrm{D}}{ }^{20}-10.1$ (c 0.25, MeOH). Analytical data, $[\alpha]_{\mathrm{D}}{ }^{25}-10.8(c$ 0.2, $\mathrm{MeOH})[26],{ }^{1} \mathrm{H}$ and ${ }^{13} \mathrm{C}$ NMR data were reported [27]. HRMS (ESI) $m / z$ : calcd for $\mathrm{C}_{20} \mathrm{H}_{40} \mathrm{O}_{6} \mathrm{Na}[\mathrm{M}+\mathrm{Na}]^{+}$: 399.2717; found: 399.2710 .

\subsubsection{Hexadecyl $\beta$-D-glucopyranoside (12)}

Yield $0.31 \mathrm{~g}, 73 \%$, white powder. $[\alpha]_{\mathrm{D}}{ }^{20}-64.5$ (c $\left.0.33, \mathrm{MeOH}\right)$. ${ }^{1} \mathrm{H}$ and ${ }^{13} \mathrm{C}$ NMR data were reported [27]. HRMS (ESI) $m / z$ : calcd for $\mathrm{C}_{22} \mathrm{H}_{44} \mathrm{O}_{6} \mathrm{Na}[\mathrm{M}+\mathrm{Na}]^{+}$: 427.3030; found: 427.3035 .

\subsubsection{Decyl $\beta$-D-galactopyranoside (13)}

Yield $0.18 \mathrm{~g}, 70 \%$, white powder. $[\alpha]_{\mathrm{D}}-23.2(c 0.45, \mathrm{MeOH}) .{ }^{1} \mathrm{H}$ NMR data were reported [8]. ${ }^{13} \mathrm{C}$ NMR (100 MHz, $\left.\mathrm{CD}_{3} \mathrm{OD}\right): \delta 104.9$ (C-1), 76.5 (C-5), 75.0 (C-3), 72.5 (C-2), $70.8\left(\mathrm{OCH}_{2}\left(\mathrm{CH}_{2}\right)_{8} \mathrm{CH}_{3}\right), 70.3$ (C-4), 62.4 (C-6), 33.1, 30.8, 30.7(2×), 30.6, 30.5, 27.1, 23.7

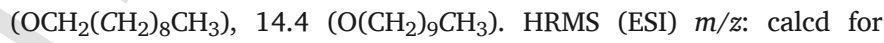
$\mathrm{C}_{16} \mathrm{H}_{32} \mathrm{O}_{6} \mathrm{Na}[\mathrm{M}+\mathrm{Na}]^{+}: 343.2091$; found: 343.2089 .

\subsubsection{Dodecyl $\alpha$-D-galactopyranoside (14)}

Yield $0.17 \mathrm{~g}, 85 \%$, white powder. $[\alpha]_{\mathrm{D}}+104.2(c$ 0.35, MeOH). ${ }^{1} \mathrm{H}$ NMR (400 MHz, CD ${ }_{3} \mathrm{OD}$ ): $\delta 4.78$ (d, $1 \mathrm{H}, J_{1,2}=3.3 \mathrm{~Hz}, \mathrm{H}-1$ ), 3.88 (dd, $\left.1 \mathrm{H}, J_{3,4}=2.8 \mathrm{~Hz}, J_{4,5}=1.2 \mathrm{~Hz}, \mathrm{H}-4\right), 3.80-3.66(\mathrm{~m}, 6 \mathrm{H}, \mathrm{H}-2$, $\left.\mathrm{H}-3, \mathrm{H}-5, \mathrm{H}-6 \mathrm{a}, \mathrm{H}-6 \mathrm{~b}, \mathrm{OCH}_{2}\left(\mathrm{CH}_{2}\right)_{10} \mathrm{CH}_{3}\right), 3.41$ (dt, $1 \mathrm{H}, J=6.5 \mathrm{~Hz}$, $\left.J=9.6 \mathrm{~Hz}, \mathrm{OCH}_{2}\left(\mathrm{CH}_{2}\right)_{10} \mathrm{CH}_{3}\right), 1.67-1.27\left(\mathrm{~m}, 20 \mathrm{H}, \mathrm{OCH}_{2}\left(\mathrm{CH}_{2}\right)_{10} \mathrm{CH}_{3}\right)$, 0.88 (t, 3H, $\left.J=6.8 \mathrm{~Hz}, \mathrm{O}\left(\mathrm{CH}_{2}\right){ }_{11} \mathrm{CH}_{3}\right) .{ }^{13} \mathrm{C} \mathrm{NMR}\left(100 \mathrm{MHz}, \mathrm{CD}_{3} \mathrm{OD}\right)$ : б 100.2 (C-1), 72.2 (C-5), 71.5 (C-3), 71.0 (C-4), 70.2 (C-2), 69.2 $\left(\mathrm{OCH}_{2}\left(\mathrm{CH}_{2}\right)_{10} \mathrm{CH}_{3}\right), 62.6(\mathrm{C}-6), 33.0,30.8(2 \times), 30.7(2 \times), 30.6(2 \times)$, 30.5, 27.3, $23.7\left(\mathrm{OCH}_{2}\left(\mathrm{CH}_{2}\right)_{10} \mathrm{CH}_{3}\right), 14.5\left(\mathrm{O}\left(\mathrm{CH}_{2}\right)_{11} \mathrm{CH}_{3}\right)$. HRMS (ESI) m/z: calcd for $\mathrm{C}_{18} \mathrm{H}_{37} \mathrm{O}_{6}[\mathrm{M}+\mathrm{H}]^{+}$: 349.2585; found: 349.2584 ; calcd for $\mathrm{C}_{18} \mathrm{H}_{36} \mathrm{O}_{6} \mathrm{Na}[\mathrm{M}+\mathrm{Na}]^{+}$: 371.2404; found: 371.2404.

\subsubsection{Dodecyl $\beta$-D-galactopyranoside (15)}

Yield $0.23 \mathrm{~g}, 87 \%$, white powder. $[\alpha]_{\mathrm{D}}-13.2$ (c 0.26, MeOH). Analytical data, $[\alpha]_{\mathrm{D}}{ }^{25}-15.8$ (c 0.54, MeOH) [34], ${ }^{1} \mathrm{H}$ and ${ }^{13} \mathrm{C}$ NMR data were reported [35]. HRMS (ESI) $m / z$ : calcd for $\mathrm{C}_{18} \mathrm{H}_{36} \mathrm{O}_{6} \mathrm{Na}[\mathrm{M}+\mathrm{Na}]^{+}$: 371.2404; found: 371.2407 .

\subsubsection{Dodecyl 1-thio- $\alpha$-D-galactopyranoside (16)}

Yield $98 \mathrm{mg}, 82 \%$, yellowish powder. $[\alpha]_{\mathrm{D}}+217.5(c 0.23$, MeOH). ${ }^{1} \mathrm{H}$ NMR (400 MHz, CD ${ }_{3} \mathrm{OD}$ ): $\delta 5.37$ (d, $1 \mathrm{H}, J_{1,2}=5.6 \mathrm{~Hz}, \mathrm{H}-1$ ), 4.18 (m, 1H, H-5), 4.07 (dd, $\left.1 \mathrm{H}, J_{2,3}=10.1 \mathrm{~Hz}, \mathrm{H}-2\right), 3.90$ (dd, $1 \mathrm{H}$, $\left.J_{4,5}=1.3 \mathrm{~Hz}, \mathrm{H}-4\right), 3.72-3.70$ (m, 2H, H-6a, H-6b), 3.61 (dd, $1 \mathrm{H}$, $\left.J_{3,4}=3.4 \mathrm{~Hz}, \mathrm{H}-3\right), 2.65-2.51\left(\mathrm{~m}, 2 \mathrm{H}, \mathrm{SCH}{ }_{2}\left(\mathrm{CH}_{2}\right)_{10} \mathrm{CH}_{3}\right), 1.67-1.26$ (m, $\left.20 \mathrm{H}, \mathrm{SCH}_{2}\left(\mathrm{CH}_{2}\right)_{10} \mathrm{CH}_{3}\right), 0.89$ (t, $\left.3 \mathrm{H}, J=6.7 \mathrm{~Hz}, \mathrm{~S}\left(\mathrm{CH}_{2}\right)_{11} \mathrm{CH}_{3}\right)$. ${ }^{13} \mathrm{C}$ NMR (100 MHz, CD $\left.{ }_{3} \mathrm{OD}\right): \delta 87.4$ (C-1), 72.6 (C-5), 72.2 (C-3), 70.9 (C-4), 69.8 (C-2), 62.6 (C-6), $33.1\left(\mathrm{SCH}_{2}\left(\mathrm{CH}_{2}\right)_{10} \mathrm{CH}_{3}\right), 30.8(3 \times)$, $30.7(3 \times), \quad 30.5, \quad 30.4, \quad 30.1, \quad 23.7 \quad\left(\mathrm{SCH}_{2}\left(\mathrm{CH}_{2}\right)_{10} \mathrm{CH}_{3}\right), \quad 14.4$ $\left(\mathrm{S}_{(} \mathrm{CH}_{2}\right)_{11} \mathrm{CH}_{3}$ ). HRMS (ESI) $\mathrm{m} / z$ : calcd for $\mathrm{C}_{18} \mathrm{H}_{36} \mathrm{O}_{5} \mathrm{SNa}[\mathrm{M}+\mathrm{Na}]^{+}$: 387.2176; found: 387.2179. 


\subsubsection{Dodecyl 1-thio- $\beta$-D-galactopyranoside (17)}

Yield 0.30 g, 85\%, yellowish powder. $[\alpha]_{\mathrm{D}}-18.9(c 0.21, \mathrm{MeOH}) .{ }^{1} \mathrm{H}$ NMR (400 MHz, CD ${ }_{3} \mathrm{OD}$ ): $\delta 4.31$ (d, $1 \mathrm{H}, J_{1,2}=9.5 \mathrm{~Hz}, \mathrm{H}-1$ ), 3.88 (dd, $\left.1 \mathrm{H}, J_{4,5}=1.2 \mathrm{~Hz}, \mathrm{H}-4\right), 3.73\left(\mathrm{dd}, 1 \mathrm{H}, J_{5,6 \mathrm{a}}=6.7 \mathrm{~Hz}, J_{6 \mathrm{a}, 6 \mathrm{a}}=11.4 \mathrm{~Hz}\right.$, H-6a), 3.68 (dd, $\left.1 \mathrm{H}, J_{5,6 \mathrm{~b}}=5.4 \mathrm{~Hz}, \mathrm{H}-6 \mathrm{~b}\right), 3.56-3.48$ (m, 2H, H-2, H-5), 3.44 (dd, $1 \mathrm{H}, J_{3,4}=3.3 \mathrm{~Hz}, \mathrm{H}-3$ ), $2.79-2.65$ (m, $2 \mathrm{H}, \mathrm{SCH}_{2}\left(\mathrm{CH}_{2}\right)_{10} \mathrm{CH}_{3}$ ), 1.67-1.27 (m, 20H, SCH $\left.{ }_{2}\left(\mathrm{CH}_{2}\right)_{10} \mathrm{CH}_{3}\right), 0.89$ (t, $3 \mathrm{H}, J=6.7 \mathrm{~Hz}$, $\left.\mathrm{S}\left(\mathrm{CH}_{2}\right)_{11} \mathrm{CH}_{3}\right) .{ }^{13} \mathrm{C}$ NMR (100 MHz, $\left.\mathrm{CD}_{3} \mathrm{OD}\right): \delta 87.7$ (C-1), 80.6 (C-5), 76.3 (C-3), 71.5 (C-2), 70.5 (C-4), 62.6 (C-6), $33.1\left(\mathrm{SCH}_{2}\left(\mathrm{CH}_{2}\right)_{10} \mathrm{CH}_{3}\right)$,

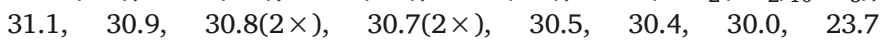
$\left(\mathrm{SCH}_{2}\left(\mathrm{CH}_{2}\right)_{10} \mathrm{CH}_{3}\right), 14.4\left(\mathrm{~S}\left(\mathrm{CH}_{2}\right)_{11} \mathrm{CH}_{3}\right)$. HRMS (ESI) $\mathrm{m} / z$ : calcd for $\mathrm{C}_{18} \mathrm{H}_{36} \mathrm{O}_{5} \mathrm{SNa}[\mathrm{M}+\mathrm{Na}]^{+}$: 387.2176; found: 387.2176 .

\subsubsection{Tetradecyl $\beta$-D-galactopyranoside (18)}

Yield $0.20 \mathrm{~g}, 75 \%$, white powder. $[\alpha]_{\mathrm{D}}-10.6(c 0.7, \mathrm{MeOH})$. Analytical data, $[\alpha]_{\mathrm{D}}{ }^{20}-8.1(c 0.8, \mathrm{MeOH})[23],{ }^{1} \mathrm{H}[23]$ and ${ }^{13} \mathrm{C}$ NMR [36] data were reported. HRMS (ESI) $m / z$ : calcd for $\mathrm{C}_{20} \mathrm{H}_{40} \mathrm{O}_{6} \mathrm{Na}[\mathrm{M}+\mathrm{Na}]^{+}$: 399.2717; found: 399.2720 .

\subsubsection{Hexadecyl $\beta$-D-galactopyranoside (19)}

Yield $0.17 \mathrm{~g}, 82 \%$, white powder. $[\alpha]_{\mathrm{D}}-8.1$ (c $\left.0.35, \mathrm{MeOH}\right)$, ref [34] $[\alpha]_{\mathrm{D}}{ }^{25}-5.9$ (c 0.51, MeOH). ${ }^{1} \mathrm{H}$ NMR (400 MHz, $\left.\mathrm{CD}_{3} \mathrm{OD}\right): \delta 4.23$ (d, $\left.1 \mathrm{H}, J_{1,2}=7.3 \mathrm{~Hz}, \mathrm{H}-1\right), 3.92(\mathrm{dt}, 1 \mathrm{H}, J=6.8 \mathrm{~Hz}, J=9.5 \mathrm{~Hz}$, $\left.\mathrm{OCH}_{2}\left(\mathrm{CH}_{2}\right)_{14} \mathrm{CH}_{3}\right), 3.86\left(\mathrm{dd}, 1 \mathrm{H}, J_{3,4}=3.2 \mathrm{~Hz}, J_{4,5}=1.1 \mathrm{~Hz}, \mathrm{H}-4\right)$, $3.76\left(\mathrm{dd}, 1 \mathrm{H}, J_{5,6 \mathrm{a}}=6.7 \mathrm{~Hz}, J_{6 \mathrm{a}, 6 \mathrm{a}}=11.4 \mathrm{~Hz}, \mathrm{H}-6 \mathrm{a}\right), 3.60-3.46(\mathrm{~m}$, $\left.4 \mathrm{H}, \quad \mathrm{H}-2, \quad \mathrm{H}-3, \quad \mathrm{H}-5, \quad \mathrm{OCH}_{2}\left(\mathrm{CH}_{2}\right)_{14} \mathrm{CH}_{3}\right), \quad 1.67-1.32 \quad(\mathrm{~m}, \quad 28 \mathrm{H}$, $\left.\mathrm{OCH}_{2}\left(\mathrm{CH}_{2}\right)_{14} \mathrm{CH}_{3}\right), 0.93\left(\mathrm{t}, 3 \mathrm{H}, J=6.9 \mathrm{~Hz}, \mathrm{O}\left(\mathrm{CH}_{2}\right)_{15} \mathrm{CH}_{3}\right) .{ }^{13} \mathrm{C} \mathrm{NMR}$ (100 MHz, CD ${ }_{3} \mathrm{OD}$ ): $\delta 105.0$ (C-1), 76.6 (C-5), 75.1 (C-3), 72.6 (C-2), $70.8\left(\mathrm{OCH}_{2}\left(\mathrm{CH}_{2}\right)_{14} \mathrm{CH}_{3}\right), 70.3$ (C-4), 62.5 (C-6), 33.1, 30.9(5×), $30.8(3 \times), \quad 30.6(2 \times), \quad 30.5, \quad 27.1, \quad 23.7\left(\mathrm{OCH}_{2}\left(\mathrm{CH}_{2}\right)_{14} \mathrm{CH}_{3}\right), \quad 14.4$

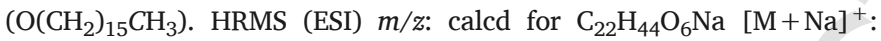
427.3030; found: 427.3033 .

\subsection{Biology}

\subsubsection{In vitro MTS assays}

Cell lines. All cell lines (if not indicated otherwise) were purchased from the American Tissue Culture Collection (ATCC). The CCRF-CEM line is derived from $\mathrm{T}$ lymphoblastic leukemia, evincing high chemosensitivity, K562 represent cells from an acute myeloid leukemia patient sample with bcr-abl translocation, U2OS line is derived from osteosarcoma, HCT116 is colorectal tumor cell line and its p53 gene knock-down counterpart (HCT116p53-/-, Horizon Discovery Ltd, UK) is a model of human cancers with p53 mutation frequently associated with poor prognosis, A549 line is lung adenocarcinoma. The daunorubicin resistant subline of CCRF-CEM cells (CEM-DNR bulk) and paclitaxel-resistant subline K562-TAX were selected in our laboratory by the cultivation of maternal cell lines in increasing concentrations of daunorubicin or paclitaxel, respectively. The CEM-DNR bulk cells overexpress MRP-1 and P-glycoprotein protein, while K562-TAX cells overexpress P-glycoprotein only. Both proteins belong to the family of $\mathrm{ABC}$ transporters and are involved in the primary and/or acquired multidrug resistance phenomenon $[37,38]$. MRC-5 and BJ cell lines were used as a non-tumor control and represent human fibroblasts. The cells were maintained in nunc/ corning $80 \mathrm{~cm}^{2}$ plastic tissue culture flasks and cultured in cell culture medium according to ATCC or Horizon recommendations (DMEM/ RPMI 1640 with $5 \mathrm{~g} / \mathrm{L}$ glucose, $2 \mathrm{mM}$ glutamine, $100 \mathrm{U} / \mathrm{mL}$ penicillin, $100 \mathrm{mg} / \mathrm{mL}$ streptomycin, $10 \%$ fetal calf serum, and $\mathrm{NaHCO}_{3}$ ).

Cytotoxic MTS assay. MTS assay was performed at the Institute of Molecular and Translational Medicine by robotic platform (HighResBiosolutions). Cell suspensions were prepared and diluted according to the particular cell type and the expected target cell density
(25000-35000 cells/mL based on cell growth characteristics). Cells were added by automatic pipettor $(30 \mu \mathrm{L})$ into 384 well microtiter plates. All tested compounds were dissolved in 100\% DMSO and four-fold dilutions of the intended test concentration were added in $0.15 \mu \mathrm{L}$ aliquots at time zero to the microtiter plate wells by the echo acoustic non-contact liquid handler Echo550 (Labcyte). The experiments were performed in technical duplicates and three biological replicates at least. The cells were incubated with the tested compounds for $72 \mathrm{~h}$ at $37{ }^{\circ} \mathrm{C}$, in a $5 \%$ $\mathrm{CO}_{2}$ atmosphere at $100 \%$ humidity. At the end of the incubation period, the cells were assayed by using the MTS test. Aliquots $(5 \mu \mathrm{L})$ of the MTS stock solution were pipetted into each well and incubated for an additional $1-4 \mathrm{~h}$. After this incubation period, the optical density (OD) was measured at $490 \mathrm{~nm}$ with an Envision reader (PerkinElmer). Tumor cell survival (TCS) was calculated by using the following equation: TCS $=\left(\mathrm{OD}_{\text {drug-exposed well }} /\right.$ mean $\left.\mathrm{OD}_{\text {control wells }}\right) \times 100 \%$. The $\mathrm{IC}_{50}$ value, the drug concentration that is lethal to $50 \%$ of the tumor cells, was calculated from the appropriate dose-response curves in Dotmatics software $[37,38]$.

Cell cycle and apoptosis analysis. CCRF-CEM cells were seeded at a density of $1 \times 10^{6}$ cells $\mathrm{mL}^{-1}$ in 6 -well plates and were cultivated with compounds at concentrations corresponding to $1 \times$ or $5 \times$ IC50. After $24 \mathrm{~h}$, cells were washed with cold $1 \times$ PBS and fixed in $70 \%$ ethanol added dropwise and stored overnight at $-20{ }^{\circ} \mathrm{C}$. Afterward, cells were washed in hypotonic citrate buffer, treated with RNase $\left(50 \mu \mathrm{g} \mathrm{mL}^{-1}\right)$ and stained with propidium iodide. Flow cytometry using a $488 \mathrm{~nm}$ single beam laser (Becton Dickinson) was used for measurement. Cell cycle was analyzed by the software ModFitLT (Verity), and apoptosis was measured in logarithmic model expressing the percentage of the particles with propidium content lower than cells in G0/G1 phase $(<\mathrm{G} 1)$ of the cell cycle. Half of the sample was used for $\mathrm{pH} 3^{\mathrm{Ser} 10}$ antibody (Sigma) labeling and subsequent flow cytometry analysis of the cells in mitosis.

BrDU incorporation analysis. Cells were cultivated as in the previous method. Before harvesting, $10 \mu \mathrm{M}$ 5-bromo-2-deoxyuridine (BrDU) was added to the cells for pulse labeling for $30 \mathrm{~min}$. The cells were washed by PBS and fixed with ice-cold $70 \%$ ethanol and stored overnight. Before analysis, they were incubated on ice for $30 \mathrm{~min}$, washed once with PBS and re-suspended in $2 \mathrm{M} \mathrm{HCl}$ for $30 \mathrm{~min}$ at room temperature to denature their DNA. Following neutralization with $0.1 \mathrm{M} \mathrm{Na}_{2} \mathrm{~B}_{4} \mathrm{O}_{7}$ (borax), the cells were washed with PBS containing $0.5 \%$ Tween-20 and $1 \%$ BSA. Staining with primary anti-BrDU antibody (Exbio) for $30 \mathrm{~min}$ at room temperature in the dark followed. Cells were then washed with PBS and stained with secondary anti-mouse-FITC antibody (Sigma). After another wash with PBS and incubation with propidium iodide $\left(0.1 \mathrm{mg} \mathrm{mL}^{-1}\right)$ and RNase A $\left(0.5 \mathrm{mg} \mathrm{mL}^{-1}\right)$ for $1 \mathrm{~h}$ at room temperature in the dark, cells were analyzed by flow cytometry using a $488 \mathrm{~nm}$ single beam laser (FACSCalibur, Becton Dickinson).

BrU incorporation analysis. Cells were cultured and treated as above. Before harvesting, pulse-labeling with $1 \mathrm{mM}$ 5-bromouridine (BrU) for $30 \mathrm{~min}$ followed. The cells were then fixed in $1 \%$ buffered paraformaldehyde with $0.05 \% \mathrm{NP}-40$ at room temperature for $15 \mathrm{~min}$, and then stored at $4{ }^{\circ} \mathrm{C}$ overnight. Before measurement, they were washed with $1 \%$ glycine in PBS, washed with PBS again and stained with primary anti-BrDU antibody cross-reacting to BrU (Exbio) for $30 \mathrm{~min}$ at room temperature in the dark. From this point, the experiment was performed exactly as in the previous method [39].

\subsubsection{Antimicrobial assay}

To assess antimicrobial potential of tested compounds, the determination of MIC (minimal inhibitory concentration) and MBC (minimal bactericidal concentration) was performed. The antimicrobial effects of compounds were tested on the reference bacterial strains: Gram-positive Staphylococcus aureus CCM 3953 and Enterococcus faecalis CCM 
4224, Gram-negative Escherichia coli CCM 3954 and Pseudomonas aeruginosa CCM 3955. Additionally, multiresistant bacterial strains: methicillin-resistant Staphylococcus aureus 4591 (MRSA), fluoroquinolone-resistant Staphylococcus aureus 16568 (FQR), fluoroquinolone-resistant Escherichia coli 16702 (FQR) and fluoroquinolone-resistant Pseudomonas aeruginosa 16575 (FQR) were used. Also, four strains of yeasts were tested: Candida albicans, Candida krusei, Candida parapsilosis and Candida tropicalis. These strains are part of the culture collection of Department of Microbiology (Faculty of Medicine and Dentistry, Palacký University Olomouc). ITEST Kryobanka B (ITEST plus s. r. o) was used for bacterial strains storage at $-80{ }^{\circ} \mathrm{C}$. For non-reference bacterial strains and yeasts an automatic system Phoenix (Becton Dickinson) and system MALDI-TOF Biotyper (Bruker Daltonics) were used for identification. The in vitro testing of antimicrobial activity was performed according to standard testing protocols and minimum inhibitory concentration (MIC) was determined as the concentration of the tested substance that visibly inhibits the growth of the bacterial/yeast strain (EUCAST). Bacteria and yeasts were grown for $24 \mathrm{~h}$ at $35{ }^{\circ} \mathrm{C}$ on blood agar (bacteria) and Sabouraud agar (yeasts) (TRIOS, Czech Republic), and microbial suspensions $\left(10^{5-6} \mathrm{CFU} / \mathrm{mL}\right)$ were prepared in $2 \mathrm{~mL}$ of buffer saline (TRIOS, Czech Republic) and used for inoculation. Tested samples were diluted exponentially in microtiter plates in Brain Heart Infusion broth (BHI, Hi-Media) and inoculated with prepared suspension followed by incubation for $24 / 48 \mathrm{~h}$ for bacteria/yeasts respectively at $35{ }^{\circ} \mathrm{C}$. MICs were then determined as the lowest concertation of tested compounds that visibly inhibited microbial growth. To determine bactericidal concentration the microtiter well's content with visibly inhibited growth was inoculated on cultivation agar and incubated for the subsequent $24 / 48 \mathrm{~h}$ at $35{ }^{\circ} \mathrm{C}$. Negative growth of microbial colonies then determined the minimal bactericidal concentration (MBC) of tested compounds. The MIC (minimum inhibitory concentration) of selected antibiotics in the reference bacterial strains is defined by standard methods of EUCAST (European Committee on Antimicrobial Susceptibility Testing) [40].

\subsection{Structural study}

Sample preparation. POPC and selected glycosides (GL) $(4,11,12$, $18,19)$ were dissolved in chloroform/methanol and mixed at $2 \mathrm{M}$ ratios GL:PL $=0.2$ and 0.5. Lipid mixtures were dried under a stream of gaseous nitrogen and the residue of organic solvents was removed under vacuum. Dried lipid films ( $8 \mathrm{mg} / \mathrm{sample}$ ) were hydrated with $300 \mu \mathrm{L}$ of $150 \mathrm{mmol} / \mathrm{L} \mathrm{NaCl}$. Samples were thoroughly homogenized (by vortexing and freezing-thawing, in several cycles). For SAXS measurement, the lipid mixture was transferred into a capillary made of special glass with a diameter of $1.5 \mathrm{~mm}$. Capillaries were sealed and prepared for X-ray scattering experiments.

Small-angle X-ray scattering (SAXS). SAXS experiments were performed at LLB CEA Saclay, France using the SAXS laboratory beamline XEUSS 2.0 (Xenocs, Sassenage, France) equipped with a Pilatus detector $(1 \mathrm{M})$. The measurement wavelength was $\lambda=0.154 \mathrm{~nm}(\mathrm{CuK} \alpha)$ and sample-detector distance $120 \mathrm{~cm}$ covering a $q$-range $0.03-0.5 \AA^{-1}$. The sample in a capillary was equilibrated at selected temperature using Linkam heating stage (Linkam Scientific, Tadworth, UK). The detector was calibrated using silver behenate. The scattered intensity is plotted as a function of the scattering vector $q=4 \pi \sin \delta / \lambda$, where $2 \delta$ is the scattering angle and $\lambda$ the wavelength of the incident beam. The patterns were corrected for the used solvent. Each peak was fitted with a Lorentzian curve above a linear background. The Lorentzian is defined by $I=I_{n} /\left(1+\left(\left(q-q_{n}\right) / \Delta q_{n}\right)^{2}\right)$, where $q_{n}(n=1,2 \ldots)$ are positions of maxima, $I_{n}$ is the intensity of the peak, and $\Delta q_{n}$ is its half width at half maximum. The repeat distance $d$ was determined from $d=2 \pi / k$, where $k$ is the slope of $q\left(\AA^{-1}\right)=f(n)$ including the origin $(0,0)$. The uncertainty in $d$ is expressed from the standard deviation of the slope.

\section{Declaration of competing interest}

The authors declare that they have no known competing financial interests or personal relationships that could have appeared to influence the work reported in this paper.

\section{Acknowledgments}

This work was supported by the Slovak Research and Development Agency (the project APVV-0484-12), Scientific Grant Agency of the Ministry of Education of Slovak Republic and Slovak Academy of Sciences (projects VEGA-2/ 0031/19 and VEGA 1/0916/16), JINR project 04-4-1121-2015/2020 and by grants from the Czech Ministry of Education, Youth and Sports (LM2015063, LM2015064), Czech health research council (16 32302 A) and by the European Regional Development Fund - Project ENOCH (No. CZ.02.1.01/0.0/0.0/16_019/ 0000868).

\section{Appendix A. Supplementary data}

Supplementary data to this article can be found online at https://doi. org/10.1016/j.carres.2019.107905.

\section{References}

[1] Glycolipids, Nature. Nature Publishing Group, 2016 Retrieved May.

[2] T. Gareth, Medicinal Chemistry-An Introduction, Wiley, West Sussex, 2002, p. 125.

[3] B. Boyd, C. Drummond, I. Krodkiewska, F. Grieser, Langmuir 16 (2000) 7359-7367.

[4] M. Inès, G. Dhouda, Carbohydr. Res. 416 (2015) 59-69.

[5] D. Wu, M. Fujio, C.-H. Wong, Bioorg. Med. Chem. 16 (2008) 1073-7083.

[6] M. Poláková, M. Beláňová, L. Petruš, K. Mikušová, Carbohydr. Res. 345 (2010) 1339-1347.

[7] N. Maeda, Y. Kokai, S. Ohtani, H. Sahara, Y. Kumamoto-Yonezawa, I. Kuriyama, T. Hada, N. Sato, H. Yoshida, Y. Mizushina, Lipids 43 (2008) 741-748.

[8] S.-X. Song, M.-L. Wu, X.-P. He, Y.-B. Zhou, L. Sheng, J. Li, G.-R. Chen, Bioorg. Med. Chem. 22 (2012) 2030-2032.

[9] S.-S. Deng, C. Zhang, H. Wang, Y. Zang, J. Li, X.-P. He, G.-R. Chen, Carbohydr. Res. 408 (2015) 114-118.

[10] F.V.M. Silva, M. Goulart, J. Justino, A. Neves, F. Santos, J. Caio, S. Lucas, A. Newton, D. Sacoto, E. Barbosa, M.S. Santos, A.P. Rauter, Bioorg. Med. Chem. 16 (2008) 4083-4092.

[11] C. Dias, A. Martins, A. Pelerito, M.C. Oliveira, M. Contino, N.A. Colabufo, A.P. Rauter, Eur. J. Org. Chem. 2019 (2019) 2224-2233.

[12] X.-L. Hu, D. Li, L. Shao, X. Dong, X.-P. He, G.-R. Chen, D. Chen, ACS Med. Chem. Lett. 6 (2015) 793-797.

[13] A. Bilková, E. Paulovičová, L. Paulovičová, M. Poláková, Monatshefte Chem. 146 (2015) 1707-1714.

[14] D. Marsh, Handbook of Lipid Bilayers, second ed., CRC Press, Taylor \& Francis Group, Boca Raton, 2013.

[15] G. Pabst, A. Hodzic, J. Štrancar, S. Danner, M. Rappolt, P. Laggner, Biophys. J. 93 (2007) 2688-2696.

[16] J.F. Nagle, S. Tristram-Nagle, Biochim. Biophys. Acta 1469 (2000) 159-195.

[17] B. Carion-Taravella, S. Lesieur, J. Chopineau, P. Lesieur, M. Ollivon, Langmuir 18 (2002) 325-335.

[18] J. Karlovská, D. Uhríková, N. Kučerka, J. Teixeira, F. Devínsky, I. Lacko, P. Balgavý, Biophys. Chem. 119 (2006) 69-77.

[19] T. Silva, R. Adao, K. Nazmi, J.G.M. Bolscher, S.S. Funari, D. Uhríková, M. Bastos, Biochim. Biophys. Acta 1828 (2013) 1329-1339.

[20] J. Watt, W.J. Spencer, Org. Biomol. Chem. 3 (2005) 1982-1992.

[21] C. Limousin, J. Cleophax, A. Petit, A. Loupy, G. Lukacs, J. Carbohydr. Chem. 16 (1997) 327-342.

[22] W. Klotz, R.R. Schmidt, Liebigs Ann. Chem. 6 (1993) 683-690.

[23] M. Milkereit, V. Thiem, Chem. Phys. Lipids 127 (2004) 47-63.

[24] S.-H. Son, C. Tano, J.-I. Furukawa, T. Furuike, N. Sakairi, Org. Biomol. Chem. 6 (2008) 1441-1449.

[25] L.Z. Szabó, D.J. Hanrahan, E.M. Jones, E. Martin, J.E. Pemberton, R. Polt, Carbohydr. Res. 422 (2016) 1-4.

[26] M. Tyagi, K.P.R. Kartha, Carbohydr. Res. 413 (2015) 85-92.

[27] X. Li, J. Turánek, P. Knötigová, H. Kudláčková, J. Mašek, D.B. Pennington, S.E. Rankin, B.L. Knutson, H. Lehmler, J. New J. Chem. 32 (2008) 2169-2179.

[28] Y. Du, Q. Pan, F. Kong, Carbohydr. Res. 323 (1999) 28-35.

[29] S.-H. Son, C. Tano, T. Furuike, N. Sakairi, Carbohydr. Res. 344 (2009) 285-290.

[30] S. Oscarson, A.-K. Tiden, Carbohydr. Res. 247 (1993) 323-328.

[31] V. Adasch, B. Hoffmann, W. Milius, G. Platz, G. Voss, Carbohydr. Res. 314 (1998) 177-187. 
[32] K. De Winter, L. Van Renterghem, K. Wuyts, H. Pelantov, V. Křen, W. Soetaert, T. Desmet, Adv. Synth. Catal. 357 (2015) 1961-1969.

[33] H.A. van Doren, R. van der Geest, R.M. Kellogg, H. Wynberg, H. Carbohydr, Res 194 (1989) 71-78.

[34] X. Zhang, T. Kamiya, N. Otsubo, H. Ishida, M. Kiso, J. Carbohydr. Chem. 18 (1999) 225-239.

[35] K.J. Sabah, R. Hashim, Tetrahedron Lett. 54 (2013) 1534-1537.

[36] A. Jakas, M. Perc, J. Su, M.C. Rodriguez, M. Cudic, P. Cudic, J. Carbohydr. Chem. 35 (2016) 69-85.

[37] V. Nosková, P. Džubák, G. Kuzmina, A. Ludková, D. Stehlik, R. Trojanec, A. Janoštáková, G. Kořínková, V. Mihal, M. Hajduch, Neoplasma 49 (2002) 418-425.
[38] P. Perlíková, G. Rylová, P. Nauš, T. Elbert, E. Tlouštová, A. Bourderioux, L.P. Slavětínská, K. Motyka, D. Doležal, P. Znojek, A. Nová, M. Harvanová, P. Džubák, M. Šiller, J. Hlaváč, M. Hajdúch, M. Hocek, Mol. Cancer Ther. 15 (2016) 922-937.

[39] A. Bourderioux, P. Naus, P. Perlikova, R. Pohl, I. Pichova, I. Votruba, P. Dzubak, P. Konecny, M. Hajduch, K.M. Stray, T. Wang, A.S. Ray, J.Y. Feng, G. Birkus, T. Cihlar, M. Hocek, J. Med. Chem. 54 (2011) 5498-5507.

[40] The European committee on antimicrobial susceptibility testingAvailable online:http://www.eucast.org 